Review

\title{
Structural Colour from Optical Phenomena Caused by Interference with a Thin or Multilayer Film, Photonic Nanocrystals, Light Scattering and Diffraction Grating Effect
}

\author{
${ }^{1}$ Relly Victoria Petrescu, ${ }^{2}$ Raffaella Aversa and ${ }^{2}$ Antonio Apicella

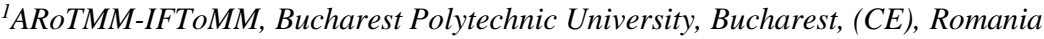 \\ ${ }^{2}$ Department of Architecture and Industrial Design, Advanced Material Lab, \\ Second University of Naples, 81031 Aversa (CE), Italy
}

\section{Article history}

Received: 27-03-2020

Revised: 25-07-2020

Accepted: 12-08-2020

Corresponding Author: Relly Victoria V. Petrescu ARoTMM-IFToMM, Bucharest Polytechnic University, Bucharest, (CE), Romania

Email: rvvpetrescu@gmail.com

\begin{abstract}
The paper presents the Ion Plating Plasma Assisted technology that is applied in the area of surface functionalization with the purpose of preserving the structural colour and relics. The interferometric structural colours applied on titanium surfaces were used and tested together with nano-transparent and at the same time achromatic films on the very old ceramic artifact. In order to test the surface restoration, some titanium metal and ceramic supports were used: Firstly, an additive with a metallic beam constructed from titanium parts was used, but also an old tile from the 19th century, having the characteristic of a strong chromatic valence and of a mixed porous and glazed surface. In the experiment, a reactive device with ionic plate spray magnetron was used, capable of operating in Argon or Oxygen environments, for the purpose of depositing $\mathrm{TiO}_{2}$ and $\mathrm{SiO}_{2}$. First, several tests were performed using two plasma treatments in order to define the optimal methods for processing. By depositing $\mathrm{TiO}_{2}$ nano-film on irregular Ti surfaces it was possible to regenerate the light direction based on the surfaces that change its colour and the transparent achromatic quality coatings could be obtained with the help of $\mathrm{SiO}_{2}$ coating. Important in these procedures is the high flexibility of ion plating technology processing. It has been established after several attempts that the treatment of IPO $\mathrm{SiO}_{2}$ surfaces is better and therefore preferable in the case of restoration and preservation of ancient historical plates when the optimized procedure with Ion Beam Electron Microscopy, performed on the porous structure of the plates, was used for final testing, which confirmed the increased flexibility and efficiency of the innovative IPPA technology.
\end{abstract}

Keywords: Aircraft, Material Science, Structural Colours, Structure, Light, Ion Plating Plasma Assisted, Ion Beam Electron Microscopy

\section{Introduction}

Looking at our daily lives, we notice that we could not carry out our activities without light. From the point of view of physics, we can say that "light colours our life". But besides the classic colours included in the ROGVAIV series, we also find structural colours.

If we talk about structural colours, it is advisable to start with the explanation of the notion of "colour" and "structural colour".

Searching in DEX (Explanatory Dictionary of the Romanian Language), we will find the following definition: Learning light determined by its spectral composition, which allows the eye to perceive differently the visible radiation incident on the retina, having the same intensity but different wavelengths. Property of bodies to absorb unevenly the different monochromatic components of light, thus modifying the composition of the light scattered or transmitted by them; the colourful appearance of the bodies.

Starting from this idea, structural colours are the colours that the eye perceives differently depending on the angle from which the same body is viewed. This phenomenon is called iridescence, being specific only to structural colours.

For example, consider a soap bubble. If we look at it, for example on the left, we will notice that it is pink. If we change our position to the right, we will 
perceive another colour (yellow, suppose). Continuing to move around the balloon, we will notice many other colours and shades.

In the same way, we can see the structural colours on the writable face of a Compact Disk. Taking a CD in your hand and moving it right-left or back-and-forth, we will notice how a series of different colours follow one another.

Plants, like animals, "get" their color in two big ways. The first way is in which the colour is given by pigments. Pigments have the ability to absorb certain waves of the light spectrum and let the rest of the waves be reflected. Thus, when we perceive the green colour of a leaf, the chlorophyll contained in it has absorbed the waves corresponding to the red and blue colour, leaving only the ones corresponding to the green colour.

The second way is to achieve the effect of structural colours. It has been highlighted much better in animals than in plants, especially in the Insect Class because it includes a considerable variety of species that show the effect of structural colours, but also in reptiles and bird feathers.

A simple observation, even for an inexperienced eye, shows that the chemical pigments appear less intense compared to the shades of structural colours, which are perceived as very intense, "vivid".

Initially, Robert Hook, interested in how peacock feathers change colour, discovered in the seventeenth century the phenomenon of iridescence. Although his theory is contradicted by Newton, then modified by Young and other physicists over time, it was eventually concluded that light is dual in nature: It has a waveform, thus explaining colours, but it also exists in the form of photons (Kinoshita and Yoshioka, 2005).

The principle behind which the perception of these colours works is the interference of light.

Interference consists of the overlapping of two or more coherent waves (where there are constant relations in time) in a certain area of space, thus obtaining a succession of maximums and minimums of interference, subsequently, this phenomenon being perceived by the eye under the shape of the structural colours.

Recent research shows that iridescence has various purposes in the living world, from visual communication, the informant on species membership, age, to sexual dimorphism and role in reproduction, but can also be observed in the inorganic matter around us.

Following an experiment with sedimented silicon suspension and obtaining a thin film of colloidal crystal, the phenomenon of iridescence was observed. The colour of silicon is white and the solution is opaque white. After obtaining the film and analyzing it, the researchers observe the structural colours. Thus, at an angle of $0^{\circ}$, the observer notices an intense pink-red colour. At the $45^{\circ}$ angle, the perceived colour is green and at the $90^{\circ}$ angle (angle where the incident waves are zero), the colour is siliceous white. Following the calculations, the researchers conclude that the perception of different colours lies in the differences in wavelengths that hit the film formed above the silicon solution (the range of observed lengths being between $207 \mathrm{~nm}$ and $350 \mathrm{~nm}$ ).

In the plant world, the colour of the floral coating is crucial for multiplication. So iridescence has a more important role in interspecific communication (plantinsect or plant-bird). In plants, iridescence is also manifested by mimicry, the plant trying to copy the shape and colour of the female of certain insects or birds specific to pollination.

The colour comes from the way we visualize the different wavelengths of light. The colours we see depend on the light reflected or transmitted by objects to our eyes. The most common source of colour is pigmentation: Almost everything we see, including our clothes and ourselves, is coloured by pigment molecules.

But there is another way to make colour - one that fruits, beetles, butterflies and peacocks, for example, have been using for a long time: Structural colour. Their colours change depending on our point of view and this is due to the microscopic structures on their surface, which interfere with the reflection of light. People used structural colours long before they knew their cause and today scientists are inspired by nature to further develop structural colour. "We try to create materials that manipulate light using the same physical principles as those found in nature," says Pete Vukusic, a professor of biophotonics at the University of Exeter, UK. "The goal is not to mask or hide things, but to give materials and objects interesting and functional optical properties, such as brightness, directionality, or iridescence"; (Kinoshita and Yoshioka, 2005).

On a sunny afternoon in the 17th century, Robert Hooke discovered something that would go down in history. Wondering why the colour of peacock feathers changes when viewed from different angles (called iridescence), he dipped a feather into the water and made an amazing discovery: The colour has disappeared. "Fantastic," he would write. Using a microscope, Hooke saw that the peacock feather was covered with a myriad of small ridges. He concluded that the fact proves that behind the colour is the reflection and refraction of light.

Hooke's explanation was soon rejected by Isaac Newton, who considered light to be made of particles (which he called "corpuscles"). But a few decades later, Thomas Young showed that light behaves like a wave, capable of interference - the phenomenon by which two waves are composed to result in a wave of higher or lower amplitude. In Young's famous experiment, with two slits practiced in an opaque screen through which light passes from a single source and is projected on a wall behind the screen. The light passing through these two slits showed a pattern alternating light and dark areas, like waves propagated in a pond and in the case of 
overlaps, the traces became stronger as the waves interfered. This behavior could be explained only by considering that a wave came out of each slot and then they interfered to amplify and attenuate in certain positions, respectively (Kinoshita and Yoshioka, 2005).

But further research would contradict Young. The gold leaf experiment showed that electrons are expelled from a metal surface when subjected to electromagnetic radiation, but only if the light has a fairly high frequency, i.e., high energy, while the intensity of the source does not influence the phenomenon. The experiment proved that light and ultraviolet rays are made up of individual units called photons.

Today we say that light also travels like a wave, but it also consists of energy packets called photons. Light has a dual nature.

Now we know: The colours of many birds and insects come from the structural colour, created by the interaction of light with certain regular structures having a size of only a few hundred nanometers. These structures decompose incident light into several reflected light waves, which interfere with each other, canceling or amplifying different wavelengths in different directions and which thus appear to our eyes as brightly coloured or iridescent. In pigmentation systems, the physics is completely different, which explains why the structural colour can be much brighter. "Pigments only reflect and absorb light. Absorbent processes, which are intrinsic to the production of colour through pigments, are the very things that limit the brightness of colours," says Vukusic.

Under certain conditions, two waves can be composed resulting in either a higher amplitude wave when the waves are in phase or a complete cancellation if the waves are in phase. In the case of structural colour, visible light decomposes when it is reflected by particular nanostructures: Certain wavelengths are consolidated and others destroyed, giving the appearance of brightly coloured or iridescent.

Not all colours in nature come from the inherent colouring of the chemical structure of the material. There are several physical phenomena that determine the surface colouration by interference or diffraction of the wavelength. The first, which is often referred to as iridescence or structural staining, has been researched since the end of the seventeenth century. Speculates that solid and thin alternate layers strongly reflect light (Hooke, 2003). Newton described (1704) in Opticks that iridescent peacock colours appeared beneath the transparent side of the feathers (Newton, 1952). The additional scientific advance on the genesis of structural colours was interpreted by (Chrystal, 1873). Chrystal (1873) and in the experimental studies of electromagnetic waves by (Hertz, 1884). Rayleigh $(1917 ; 1919)$ used electromagnetic theory to derive the theory to express the reflectance properties of a regular stratified environment (Rayleigh, 1917; 1919). This theory was based on the explanation of the nature of the colours of crystals, feathers and cockroaches and butterflies (Kwok et al., 1997). which varied with the incidence of light direction, not the inherent colours, but the colour of the structure (Aronov et al., 2007).

The study and understanding of the natural structural colouration of insects and bird feathers are of great interest, as their use could find applications in many commercial fields related to the aesthetics of the product, such as colouring of metals, dental implants, cosmetics and textiles.

A complete understanding of these structures was obtained for the first time with the use of electron microscopy and, more recently, by double-beam ion microscopy and atomic force microscopy, which allowed us to visualize the micro-morphology and nanostructure of the structural generation that appear natural as systems.

These studies (Kinoshita and Yoshioka, 2005) clarified that the staining is due to the presence of specific micro and nanostructures, which cannot be easily achieved by known nanotechnologies, which must then be further developed technologically.

Essentially, these structural colours come from optical phenomena caused by interference with a thin or multilayer film, photonic nanocrystals (quantum dots), light scattering and a diffraction grating effect. During evolution, living beings have developed different microstructural models that simultaneously achieve high reflectivity for specific wavelength intervals, while generating wide-angle diffusive light. Even though these two physical characteristics seem to be optically opposed to each other, when combined in appropriate combinations where morphological regularity and irregularity require specific configurations, the resulting system is capable of filtering and enhancing specific colours.

The paper presents the Ion Plating Plasma Assisted technology that is applied in the area of surface functionalization with the purpose of preserving the structural colour and relics. The interferometric structural colours applied on titanium surfaces were used and tested together with nano-transparent and at the same time achromatic films on the very old ceramic artifact. In order to test the surface restoration, some titanium metal and ceramic supports were used: Firstly, an additive with a metallic beam constructed from titanium parts was used, but also an old tile from the 19th century, having the characteristic of a strong chromatic valence and of a mixed porous and glazed surface. In the experiment, a reactive device with ionic plate spray magnetron was used, capable of operating in Argon or Oxygen environments, for the purpose of 
depositing $\mathrm{TiO}_{2}$ and $\mathrm{SiO}_{2}$. First, several tests were performed using two plasma treatments in order to define the optimal methods for processing. By depositing $\mathrm{TiO}_{2}$ nano-film on irregular Ti surfaces it was possible to regenerate the light direction based on the surfaces that change its colour and the transparent achromatic quality coatings could be obtained with the help of $\mathrm{SiO}_{2}$ coating. Important in these procedures is the high flexibility of ion plating technology processing. It has been established after several attempts that the treatment of IPO $\mathrm{SiO}_{2}$ surfaces is better and therefore preferable in the case of restoration and preservation of ancient historical plates when the optimized procedure with Ion Beam Electron Microscopy, performed on the porous structure of the plates, was used for final testing, which confirmed the increased flexibility and efficiency of the innovative IPPA technology (Kinoshita and Yoshioka, 2005).

In this study, one presents exploratory investigations that combine simple and complex surface morphologies to explain some fundamental optical properties underlying structural colours.

Over thousands of years of evolution, living organisms have learned ways to manipulate light using delicate and periodically arranged nanostructures. Peacocks, for example, use the structural colours of their feathers as part of mating rituals. Today, these biological models inspire engineers to look for ways to control light through optical technologies. Scientists are working to create reflective screens for e-books or e-paper that no longer need their own light source to read. Such screens would use much less power than the backlit versions of computers, smartphones and TVs. In fact, people have long used structural colour without even being aware of its principle.

The Lycurgus Cup is a Roman artifact housed in the British Museum in London, UK. Made of glass, it changes colour from green to red depending on whether the incident light is reflected by the glass or passes through it. Like peacock feathers, the stunning colour of the Lycurgus glass is due to the structural colour, being caused by small structures of only a few nanometers gold nanoparticles scattered inside the glass. When the surfaces of metal nanoparticles interact with light, they filter/diminish certain colours and favor others. Roman glassmakers found out by chance that the precious metals added to glass give impressive colour effects, but they could not reproduce the effect, so today we have few similar pieces, made around the 4th century BC.

Today, people can finally use the science of structural colour to make many items, including lipstick in the bag. By using particles made of several thin layers and by immersing them immersed in the formula we obtain an iridescent lipstick. "The regular nanostructures contained in these particles strongly reflect the colours, giving dramatic aspects and selective appearances in different directions."
The simplest transparent coating with a single thin film was investigated for application in the conservation of cultural heritage, while the complex surface morphologies obtained by depositing a thin plasma-assisted film were investigated to obtain the colour surface change.

The preservation of cultural heritage is a general concern and the use of non-invasive techniques for protecting and preserving ancient materials is an important challenge. Serious effects of surface deterioration in ancient pavements exposed to the environment, glazed ceramic tiles appear both from the mechanical abrasion due to the tourist passage and to the development of microorganisms (algae/fungi) in the pore system. Exfoliation often results from biodegradation processes that are particularly harmful, as they have resulted in severe deterioration of the decorated glaze (Silva et al., 2013; Ventolà et al., 2014). The use of traditional treatments of organic resin or wax can partially reduce the problem, but can seriously alter the chromatic aesthetics of the plates. Therefore, cleaning and preserving these ancient cultural crafts require a surface process by applying innovative non-invasive techniques. The present work is intended to contribute to the implementation of new technologies for the deposition of functional coatings in the area of biomedicine, the design and the protective coatings that prevent the degradation of the ancient plates.

The development in the protection treatment in which the introduction of an IPPA process by the thermal source (Misiano, 2001; Misiano and Scandurra, 2006; Mattox, 1964) seems to be very promising in terms of the process using traditional organic polymeric coatings. Increased demand for multilayer thin layers opens new applications for sputter technology. The deposition of the high-strength oxide layers, such as $\mathrm{SiO}_{2}$ and $\mathrm{TiO}_{2}$ used in this study has proved to be quite satisfactory innovation, having practical importance in several fields of application. The use of such techniques in the field of conservation of aesthetic and historical heritage is presented in this study.

Modification of the bioactive surface and the aesthetic effect can be obtained by designing the system according to destructive and constructive interference, by choosing the transparent coating material with the correct refractive index, the nanometric thickness of the coating and the morphology of the reflecting surface.

Functional coatings for early bone growth can be combined with the aesthetic appearance that may be required in some surgical situations (cosmetic surgery to replace the dental implant (Rulkov et al., 2016). Agarwala, (2016; Babayemi, 2016; Gusti, 2016; Mohamed et al., 2016; Wessels and Raad, 2016; Rajput et al., 2016; Rea and Ottaviano, 2016; Zurfi and 
Zhang, 2016a-b; Zheng and Li, 2016; Buonomano et al., 2016a-b; Faizal et al., 2016; Ascione et al., 2016; Elmeddahi et al., 2016; Calise et al., 2016; Morse et al., 2016; Abouobaida, 2016; Rohit and Dixit, 2016; Kazakov et al., 2016; Alwetaishi, 2016; Riccio et al., 2016a-b; Iqbal, 2016; Hasan and El-Naas, 2016; AlHasan and Al-Ghamdi, 2016; Jiang et al., 2016; Sepúlveda, 2016; Martins et al., 2016; Pisello et al., 2016; Jarahi, 2016; Mondal et al., 2016; Mansour, 2016; Al Qadi et al., 2016b; Campo et al., 2016; Samantaray et al., 2016; Malomar et al., 2016; Rich and Badar, 2016; Hirun, 2016; Bucinell, 2016; Nabilou et al., 2016; Barone et al., 2016; Chisari and Bedon, 2016; Bedon and Louter, 2016; Dos Santos and Bedon, 2016; Minghini et al., 2016; Bedon, 2016; Jafari et al., 2016; Chiozzi et al., 2016; Orlando and Benvenuti, 2016; Wang and Yagi, 2016; Obaiys et al., 2016; Ahmed et al., 2016; Jauhari et al., 2016; Syahrullah and Sinaga, 2016; Shanmugam, 2016; Jaber and Bicker, 2016; Wang et al., 2016; Moubarek and Gharsallah, 2016; Amani, 2016; Shruti, 2016; Pérez-de León et al., 2016; Mohseni and Tsavdaridis, 2016; Abu-Lebdeh et al., 2016; Serebrennikov et al., 2016; Budak et al., 2016; Augustine et al., 2016; Jarahi and Seifilaleh, 2016; Nabilou, 2016; You et al., 2016; Al Qadi et al., 2016a; Rama et al., 2016; Sallami et al., 2016; Huang et al., 2016; Ali et al., 2016; Kamble and Kumar, 2016; Saikia and Karak, 2016; Zeferino et al., 2016; Pravettoni et al., 2016; Bedon and Amadio, 2016; Chen and Xu, 2016; Mavukkandy et al., 2016; Yeargin et al., 2016; Al Madani and Dababneh, 2016; Alhasanat et al., 2016; Elliott et al., 2016; Suarez et al., 2016; Kuli et al., 2016; Waters et al., 2016; Montgomery et al., 2016; Lamarre et al., 2016; Petrescu, 2012b; Aversa et al., 2017a-b, 2016a-o; Petrescu and Petrescu, 2016; 2015a-e; 2014a-I; 2013a-g; 2012; 2011; 2005a-d; 2003; 2002a-b; 2000a-b; 1997a-c; 1995a-b; Petrescu, 2018; 2015a-b; 2012; Petrescu et al., 2016; 2017a-d; 2018a-d; Petrescu and Calautit, 2016a-b; Daud et al., 2008; Taher et al., 2008; Zulkifli et al., 2008; Pourmahmoud, 2008; Pannirselvam et al., 2008; $\mathrm{Ng}$ et al., 2008; El-Tous, 2008; Akhesmeh et al., 2008; Nachiengtai et al., 2008; Moezi et al., 2008; Boucetta, 2008; Darabi et al., 2008; Semin and Bakar, 2008; AlAbbas, 2009; Abdullah et al., 2009; Abu-Ein, 2009; Opafunso et al., 2009; Semin et al., 2009a-c; Zulkifli et al., 2009; Ab-Rahman et al., 2009; Abdullah and Halim, 2009; Zotos and Costopoulos, 2009; Feraga et al., 2009; Bakar et al., 2009; Cardu et al., 2009; Bolonkin, 2009a-b; Nandhakumar et al., 2009; Odeh et al., 2009; Lubis et al., 2009; Fathallah and Bakar, 2009; Marghany and Hashim, 2009; Kwon et al., 2010; Aly and Abuelnasr, 2010; Farahani et al., 2010; Ahmed et al., 2010; Kunanoppadon, 2010; Helmy and El-Taweel, 2010; Qutbodin, 2010; Pattanasethanon, 2010; Fen and Yunus,
2011; Thongwan et al., 2011; Theansuwan et al., 2011; Al Smadi, 2011; Tourab et al., 2011; Raptis et al., 2011; Momani et al., 2011; Ismail et al., 2011; Anizan et al., 2011; Tsolakis and Raptis, 2011; Abdullah et al., 2011; Kechiche et al., 2011; Ho et al., 2011; Rajbhandari et al., 2011; Aleksic and Lovric, 2011; Kaewnai and Wongwises, 2011; Idarwazeh, 2011; Ale Ebrahim et al., 2012; Abdelkrim et al., 2012; Mohan et al., 2012; Abam et al., 2012; Hassan et al., 2012; Jalil and Sampe, 2013; Abou Jaoude and El-Tawil, 2013; Ali and Shumaker, 2013; Zhao, 2013; El-Labban et al., 2013; Djalel et al., 2013; Nahas and Kozaitis, 2014).

\section{Materials and Methods}

\section{$Y$ Materials}

For tests, titanium samples, additives with complex structure and ceramic tiles were used: A 19th-century tile and two contemporary product plates, all characterized by strong chromatic valence and porous plates and glazed surfaces.

\section{Testing Procedures and Apparatus}

Ion Plating Plasma Assisted (IPPA) - Two surface coating procedures have been tested and compared on contemporary surfaces: Nano-shaped plasma protection films with $\mathrm{TiO}_{2}$ type and $\mathrm{SiO}_{2}$ type.

Sputtering is a PVD coating technology. Inert gas atoms are sent in a high vacuum environment at very low pressure (generally below 10 mTorr), where their atoms are ionized, creating a gas-like atmosphere, which will cause them to collide with the target (in case of Ti or our silicon oxide).

These collisions allow the target atoms to eject to the substrate in the wind, where it condenses into a thin film. We can configure systems that allow RF sputtering and different target sources (such as thermal or magnetron).

The strong magnetic field created in the sputtering process results in the limitation of the ions and electrons generated in the plasma in a designated area near the source target. This particular configuration generates more collisions between ions and neutral gas molecules, creating more ions that could collide with the source target, which eliminates larger amounts of base coating material ( $\mathrm{Ti}$ or $\mathrm{SiOx}$ in our study). Due to the presence of a larger number of ions and an electric field, this process allows a higher deposition rate.

Magnetron sputtering helps reduce thin film damage, as the magnetic field guides electrons to travel on specific paths without hitting the substrate.

Due to the high energy of the material discharged from the target, magnetron-sputtering technology creates very dense and high adhesion coatings. 
Moreover, when a reactive gas, such as oxygen or nitrogen, is introduced into the spray chamber; reactions occur with these ionized gases to form oxide and nitrate films. In the reactive spray, the sprayed particles undergo a chemical reaction before coating the substrate and then the deposited coating has a different composition from the target material.

The two Ion Plating assisted plasma deposition equipment, with a magnetron sputter lens and thermal source, consisted of a high vacuum chamber containing $\mathrm{Ti}$ sources for the spray source and $\mathrm{SiOx}$ for the thermal source attached to a magnetron sputter source.

The DC power source (Fig. 1).

The magnetron spray source uses heavy magnetic and electrical fields to limit the charged plasma particles near the spray target surface.

A mixture of Argon and Oxygen Gas was introduced into the room, along with the samples. The percentage of ionized storage materials (titanium or $\mathrm{SiOx}$ particles) emitted by DC or thermal sources is accelerated by a negative bias produced by an electric Radio Frequency (RF) field applied to the substrate support. Such a radio frequency produces plasma in the processing atmosphere, which produces ionization of the depositing materials and produces ionic bombardment of Argon and Oxygen on the rising film (Misiano, 2001; Misiano and Scandurra, 2006; Mattox, 1964).

Ion Plating Plasma Assisted source by magnetron sputtering with Argon atmosphere Preliminary Vacuum $7,0 \times 10^{-5}$ mbar and an Argon atmosphere of $3,0 \times 10^{-3}$ mbar, $\mathrm{O}_{2}$ pressure $410^{-4}$ mbar was used to deposit $\mathrm{TiO}_{2}$ in the plant Balzer BA 710 (IPPARCUS), with a Ti target. The deposited Titanium Dioxide was characterized by a high Refractive Index of 2.4.

The second film deposition test was carried out from the heat source with $\mathrm{SiO}_{\mathrm{x}}$ : Argon atmosphere preliminary

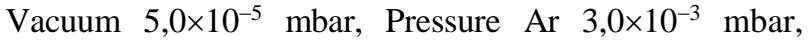
Pressure $\mathrm{O}_{2} 1.8 \times 10^{-4}$ mbar.

The $\mathrm{SiO}_{2}$ thin film deposition carried out at pressure of $\mathrm{Ar} 3,0 \times 10^{-3}$ mbar reached a deposition rate 3.5 $\mathrm{nm} / \mathrm{sec}$ leading to a coating with an average thickness of $500 \mathrm{~nm}$, Radiofrequency was $24 \mathrm{~W}, 200 \mathrm{~V}$ bias with evaporation of $\mathrm{SiOx}$. The deposited Silicon dioxide showed a Refractive Index 1.46.

The coated samples were spectro-photo-metrically verified as reported in Fig. 2 where the \% reflection as a function of light radiation wavelength are reported for a 500 $\mathrm{nm} \mathrm{SiO}_{2}$ coating on glass substrate (Aversa et al., 2016g).

\section{Results and Discussion}

\section{Protective Coating - $\mathrm{TiO}_{2}$ IPPA Coating on Ceramic Support}

Once the tests performed the result of IPPA treatment on semi-glazed plates with $\mathrm{TiO}_{2}$ deposition can be shown in Fig. 3 (left).
The treatment in question, can guarantee a homogeneous and transparent deposition of the film, but it is also characterized by an obvious change of colour of the glazed surfaces, fact due to the too high refractive index (2.4) which for this specific thickness of the thin film $(400 \mathrm{~nm})$ produces shades of pinkgreen colour, due to the reflection of the built interference shown in Fig. 4.

It is specified that the porous surface is not altered by the presence of thin-film coating (approximately $400 \mathrm{~nm}$ ).

\section{Protective Coating - $\mathrm{SiO}_{2}$ IPPA Coating on Ceramic Support}

A second IPPA treatment using $\mathrm{SiO}_{2}$ is shown in Fig. 2 (left). This treatment is able to guaranty a homogeneous and achromatic transparent film deposition.

This behavior can be clarified the consideration to be done according to the physics of coating light transmission properties reported in Fig. 4.

The reflected and refracted light paths and intensities depend upon the incident light wavelength $\left(\lambda_{1}\right.$ and $\left.\lambda_{2}\right)$, coating and substrate refractive indices, thickness of the coating $(\mathrm{L})$ and the angle of the incident light.

As light passes through an uncoated glass substrate, approximately $4 \%$ will be reflected at each interface. This results in a total transmission of only $92 \%$ of the incident light.

Anti-reflection coatings are particularly important if the coated surface has to preserve its aesthetic quality.

The coating is designed so that the relative phase shift between the beam reflected at the upper and lower boundary of the thin film is $180^{\circ}$. Destructive interference between the two reflected beams occurs, cancelling both beams before they exit the surface (upper part of Fig. 4).

The optical thickness of the coating must be an odd number of quarter wavelengths $(\lambda / 4$, where $\lambda$ is the design wavelength or wavelength being optimized for peak performance), in order to achieve the desired path difference of one half wavelength between the reflected beams, which leads to their cancellation.

The image of the unglazed tile surface after $\mathrm{SiO}_{2}$ Ion assisted plasma coating is shown in Fig. 5 .

The surface shows the presence of sub-micron pores that have not been obstructed by the plasma treatment. The aesthetics of the porous surface with no glaze is not altered by the presence of the $\mathrm{SiO}_{2}$ thin film coating, which has been evaluated from SEM microscopy to be of about 350-400 $\mathrm{nm}$ ).

Figure 6 reports the Ion beam transverse section obtained in a FEI, Scios DualBeam SEM microscope of the unglazed tile surface treated plasma coated of $\mathrm{SiO}_{2}$. 
The cross-section (from the bottom of Fig. 6) of the plate that was not cut indicates a very porous internal structure, having an irregular porous size of 0.5-3,0 $\eta \mathrm{m}$ (Fig. 6 and 7). Inside the pores, we could see the appearance of bulb-like formations of 350-400 $\mathrm{nm}$ which are not visible in the pores of the untreated reference tile samples with Ion-assisted deposition (see the lower part of Fig. 7).

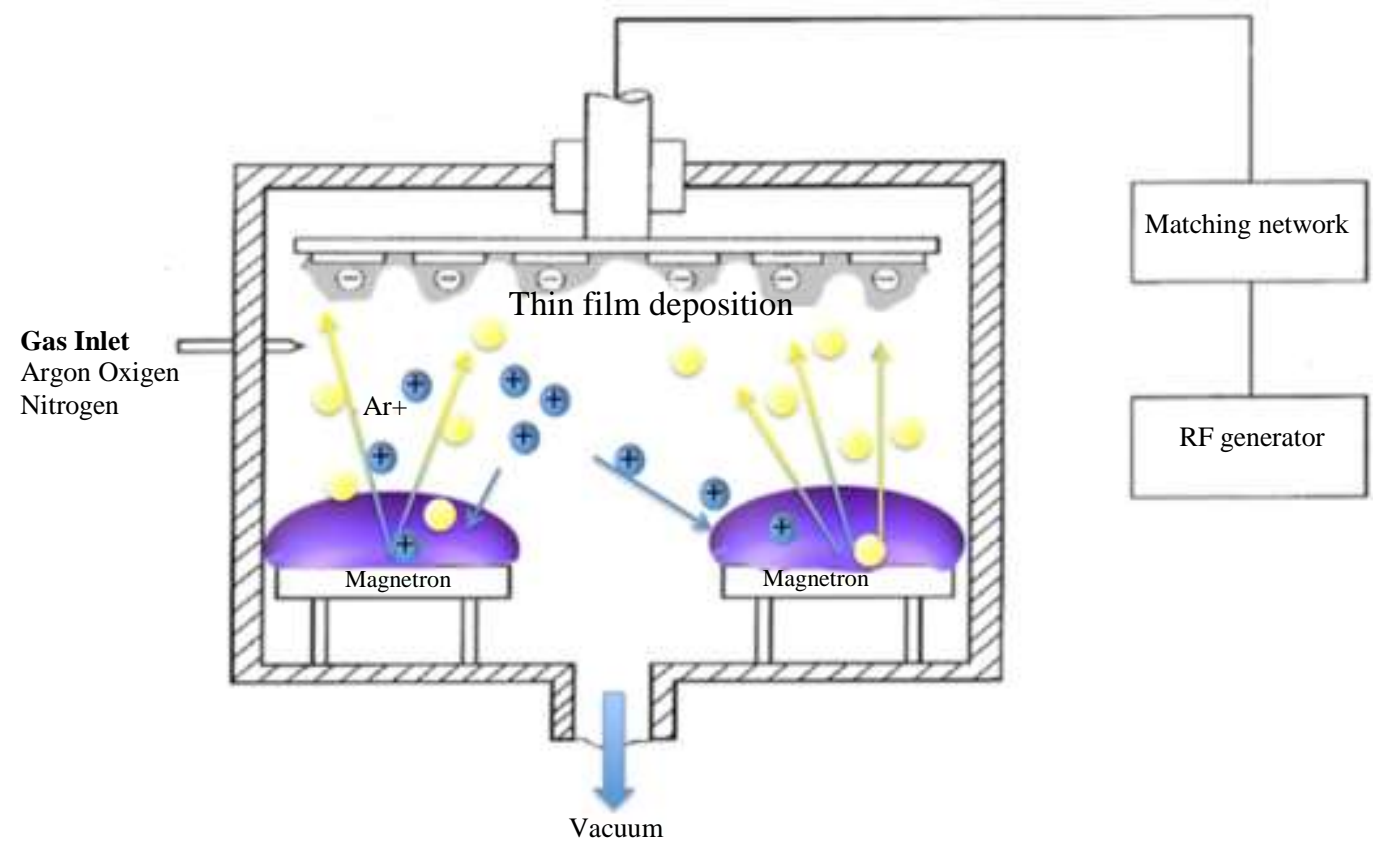

Fig. 1: Experimental set-up for Ion Plating Plasma Assisted (IPPA) from thermal and magnetron sources for transparent $\mathrm{SiO}_{2}$ and $\mathrm{TiO}_{2}$ deposition

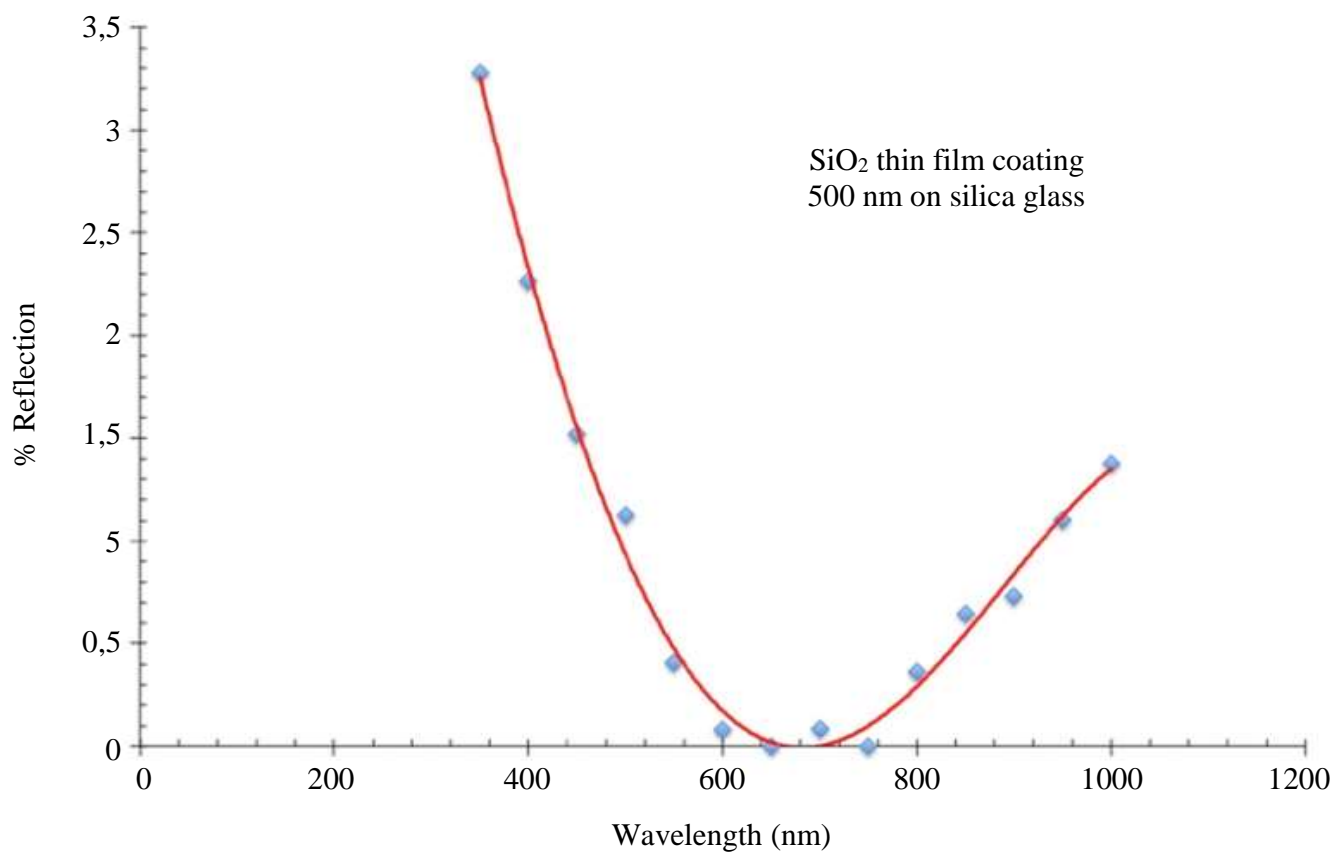

Fig. 2: Reflection \% for Ion Plating Plasma Assisted (IPPA) $\mathrm{SiO}_{2}$ protective thin film coating on silica glass 


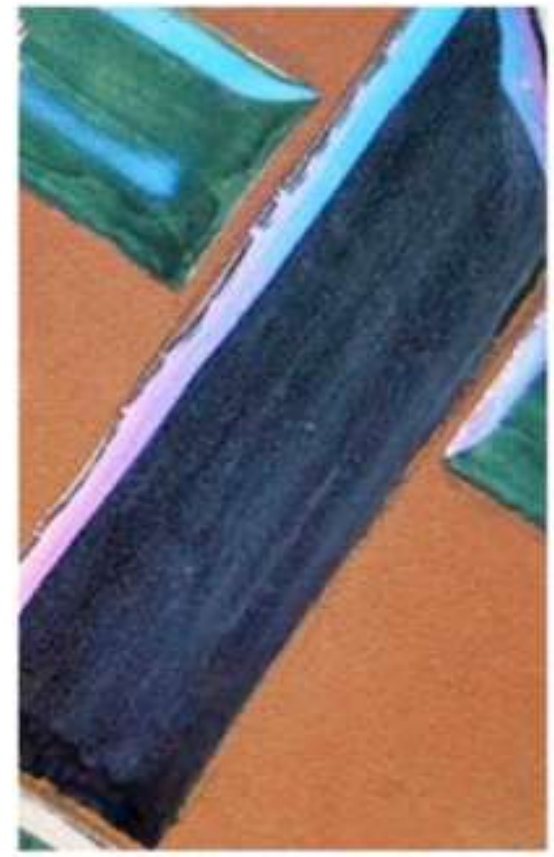

$\mathrm{TiO}_{2}$ thin film coating

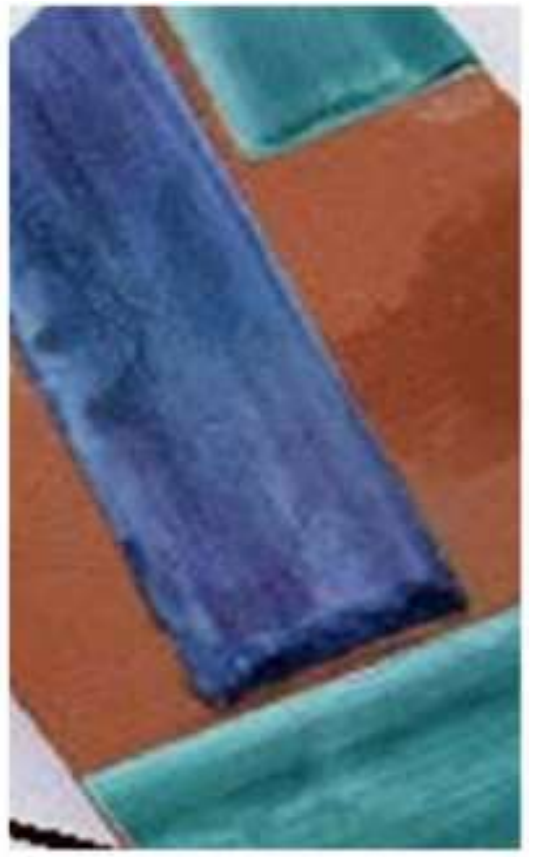

$\mathrm{SiO}_{2}$ thin film coating

Fig. 3: Ion Plating Plasma Assisted (IPPA) $\mathrm{TiO}_{2}$ (Left) and $\mathrm{SiO} 2$ (Right) protective thin film coating on ceramic tiles

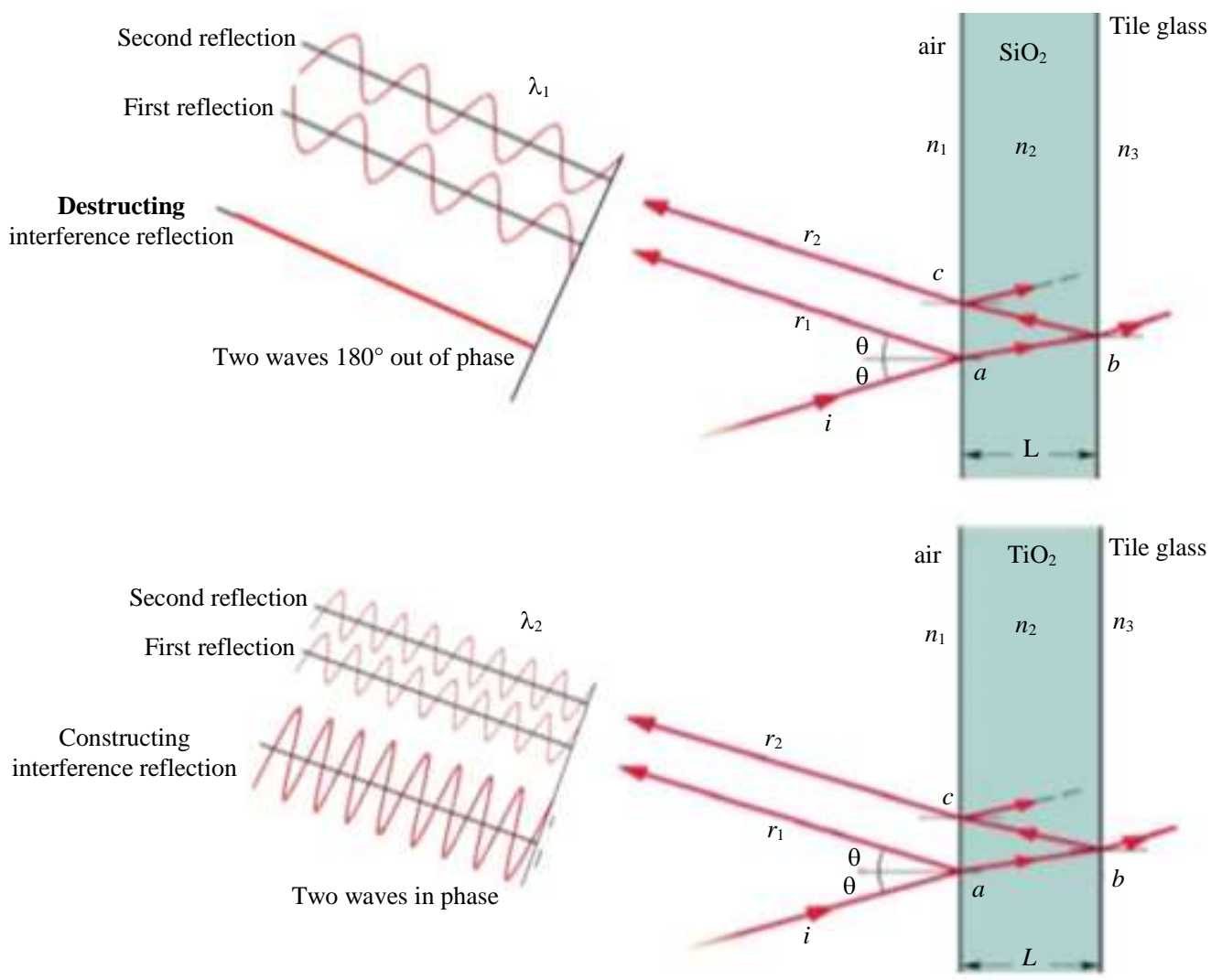

Fig. 4: Destructive and Constructing interference reflection effect in planar thin films of $\mathrm{SiO}_{2}$ (upper part) and $\mathrm{TiO}_{2}$ (lower part) 


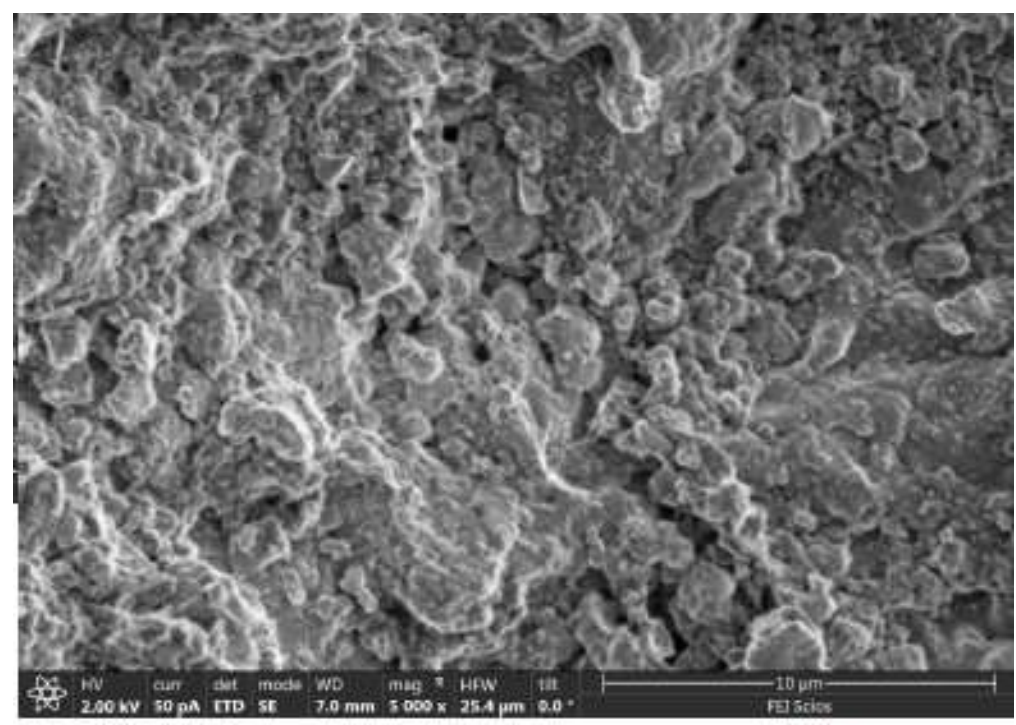

Fig. 5: Dual Beam FEI Microscopy of $\mathrm{SiO}_{2}$ coated surface of the unglazed part of the tile

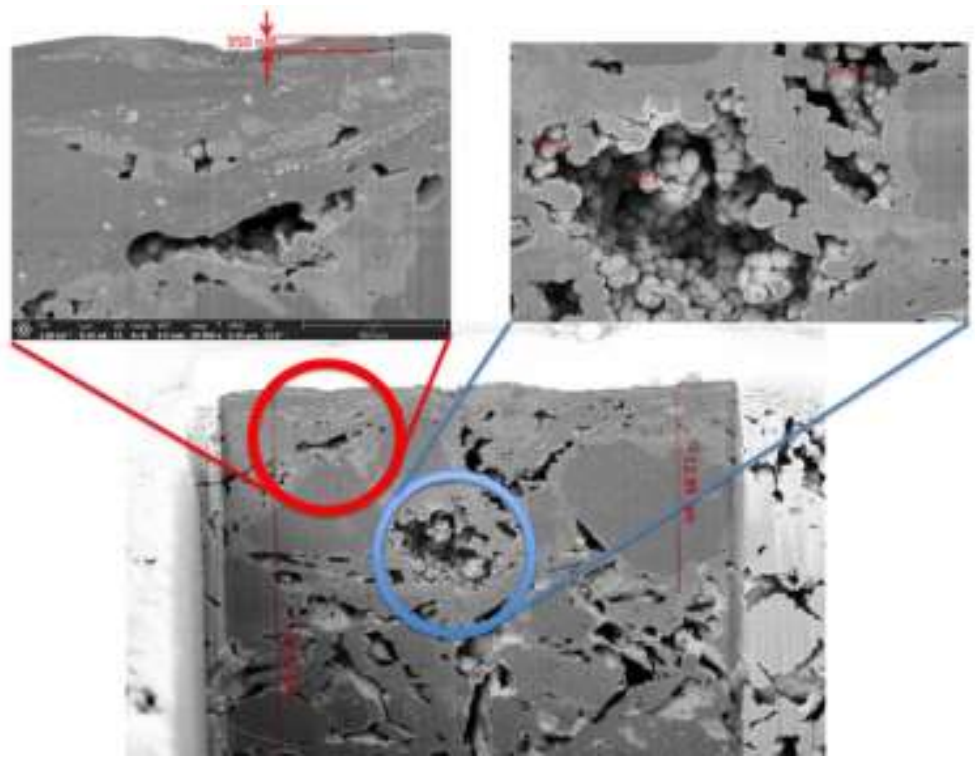

Fig. 6: Upper part-Details of Dual Beam FEI Microscopy of $\mathrm{SiO}_{2}$ coated porous tile. Bottom Ion Beam section of the porous ceramic tile

Figure 7 shows the micrograph of the cross-sections of the ion beam for IPPA layers (top) coated with plasma-assisted plasma and of the uncoated (bottom) part of an unpaired porous plate.

It was easy to see that the outer surface of the plates was uniformly coated with a constant thickness layer of approximately 350-400 nm (detail in the upper left in Fig. 7). In this way, we deduce that the coating of the plate does not only concern the surface, but is also penetrated into the internal cavities of the pores.

And even if the pores have a small lumen, they are not obstructed by plasma deposition.
For this reason, we would expect the presence of the coating treatment inside the pores to guarantee much more effective protection against the penetration of liquid water into the porosity of the ceramic tiles, thus reducing the risk of unwanted growth of the fungi or mold over time. The otherwise irregular growth of the spheroid $\mathrm{SiO}_{2}$ crystal covers the entire surface of the pore wall, creating in this way a continuous and hard layer.

The effect of roughness on the contact angle and surface wettability is relevant (Aronov et al., 2007). Meiron et al. (2004; Nosonovsky and Bhushan, 2008). Patankar (2003) and several examples can be found in 
nature, such as the Lotus leaves, where surface morphology cooperates with surface tensions to generate "superhydrophobicity" (Soeno et al., 2004; Spori et al. 2008).

Observing the roughness of silicon dioxide suggests that the harder the surface, the more it can reject water. In this way, by controlling the surface structure of a substrate, it is possible to reduce the wettability and improve the hydrophobicity of the respective layer. Soeno et al. (2004) points out that surfaces covered with $\mathrm{SiO}_{2}$ more strongly reject water. which can be justified by the apparent contact angles, surface morphologies and the ability to catch the air of uneven surfaces.

Cassie model of wetting has been used Equation 1, (Kwok et al., 1997; Yoshimitsu et al., 2002; Letellier et al., 2007; Vukusic et al., 1999) to describe the effect of roughness on apparent contact angle variations:

$\cos \theta=f(\cos \theta+1)-1$

where, $\theta^{\prime}$ is the apparent contact angle of the rough surface, $\mathrm{f}$ is the fractional area of the solid over the gas phases contact with the wetting liquid, namely the ratio between the wetted area and the overall surface area and $\theta$ is the contact angle on a flat surface, namely the Young contact angle (Spori et al., 2008; Yoshimitsu et al., 2002; Letellier et al., 2007; Vukusic et al., 1999; Kinoshita et al., 2002).

This model, even if the true contact angle of a liquid on a smooth surface is less than $90^{\circ}$, provides that the contact angle can be improved (this is due to trapped air bubbles that decrease the wet fraction of the solid surface).

The spheroidal shape of the particles creates a new high surface that can be evaluated from their average diameter (330 nm in Fig. 6). The dense packing of the spheroids for the surface of a pore cavity of the same size (lower part of Fig. 6) results in the evaluation of a roughness factor between 4.5 and 6.0 and an increased surface area for air capture (Al Dharrab et al., 2017; Aversa et al., 2016i).

According to Equation 1, a true silica-water contact angle of $15^{\circ}-20^{\circ}$ and a fraction of air trapped on the plasma generated the uneven surface of $\mathrm{SiO}_{2}$ in the pore cavities of 0.5 could lead to an increase of the apparent contact over $90^{\circ}$ (hydrophobicity).

An ion-assisted plasma treatment using $\mathrm{SiO}_{2}$ coating on the porous ceramic substrate, therefore, produces a flat outer surface characterized by good wetting and uneven surfaces of the pore cavities, which are characterized by hydrophobicity, which could be avoided. Liquid penetration and stagnation in the pores.

By choosing a deposited film material with a larger contact angle (such as $\mathrm{TiO}_{2}$ or other fluorinated substances, super-hydrophobic surfaces can be generated.

\section{Structural Colours - $\mathrm{TiO}_{2}$ IPPA Coating on Ti Metal Support}

The deposition of IPPA $\mathrm{TiO}_{2}$ on metal support obtained by the additive manufacturing technology using Ti powder was made in the same experimental state used for the ceramic support.

The use of metal support will increase the percentage of light that will be reflected in the object. This occurrence will exacerbate the effect of destroying and building the reflection of interference in the $\mathrm{TiO}_{2}$-coated system. He previously discussed that the strong coating of refractory titanium oxide (refractive index 2.4) could favour this phenomenon by creating a coloured interference-effect in the flat surface coating of the glazed ceramic support (Fig. 3) (Kinoshita et al., 2002).

In the case of an extremely reflective metal surface and several simultaneous reflections, this effect of the "filtering" of colours and the "iridescence" of the treated surfaces is exalted. The iridescence effect will depend on the morphology of the surface, the refractive index of the transparent coating and its thickness. The more irregular the surface and the greater the impact, the greater the number of internal reflexes and, consequently, the intensity of the colour filtering and the iridescence effect (structural colours).

Figure 8 shows this iridescent effect on a complexshaped Ti object obtained by the additive manufacturer with the Ti electron beam.

A detail of the irregular and hit surface of the object is presented in the lower central part of Fig. 8.

The change of $20^{\circ}$ in the direction of the sun's appearance causes a drastic change of the visualized colour.

The golden-green colour of the sample hit by sunlight at $90^{\circ}$ turns to a vivid purple when sunlight hits the object at an angle of $70^{\circ}$. The structural colours generated by the $\mathrm{TiO}_{2}$ coating are similar to those observed for peacock feathers (upper left of Fig. 7) and other birds.

This effect can be related to the physical phenomenon described in Fig. 4 (bottom) in the case of multiple reflections.

It has been described by (Kinoshita and Yoshioka, 2005) that multiple reflexes in regular or irregular surface morphology can create colour enhancement or cancellation effects (Kinoshita et al., 2002).

\section{Some Examples}

Before showing various colour-producing structures, it is best to describe the characteristics of Morpho butterflies as the most representative animals of structural colour.

Morpho butterflies, shown in Fig. 9, live in the south and Central America and according to the recent classification (Kinoshita et al., 2008). They are classified in the family Nymphalidae, which consists of several subfamilies including Morfinae closely related to the 
subfamily Satyrinae. Morpho is classified further into three tribes, of which the Morphinae tribe belongs.
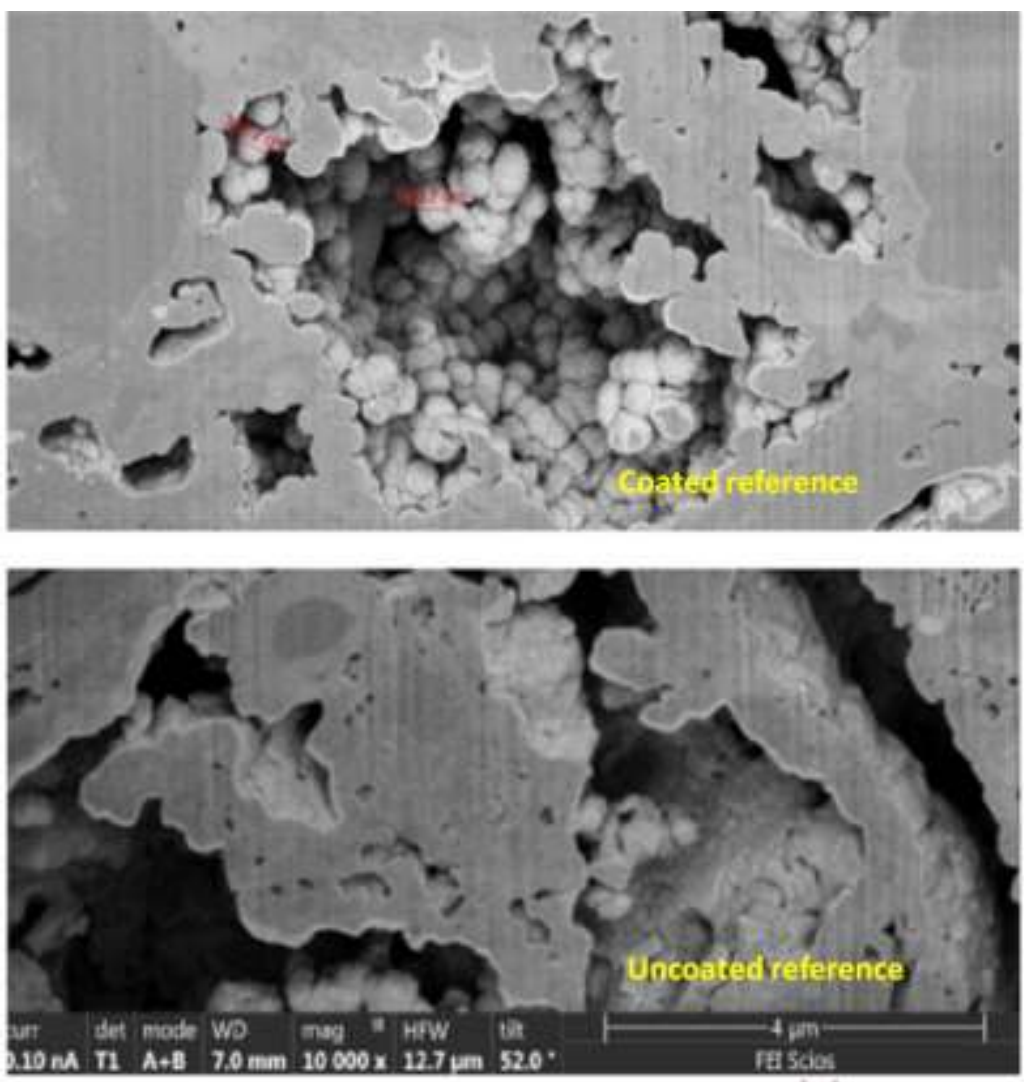

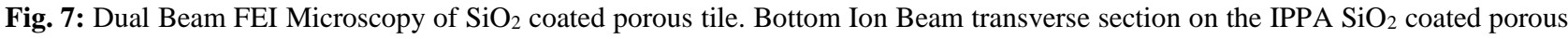
tile (top) and of an uncoated reference tile

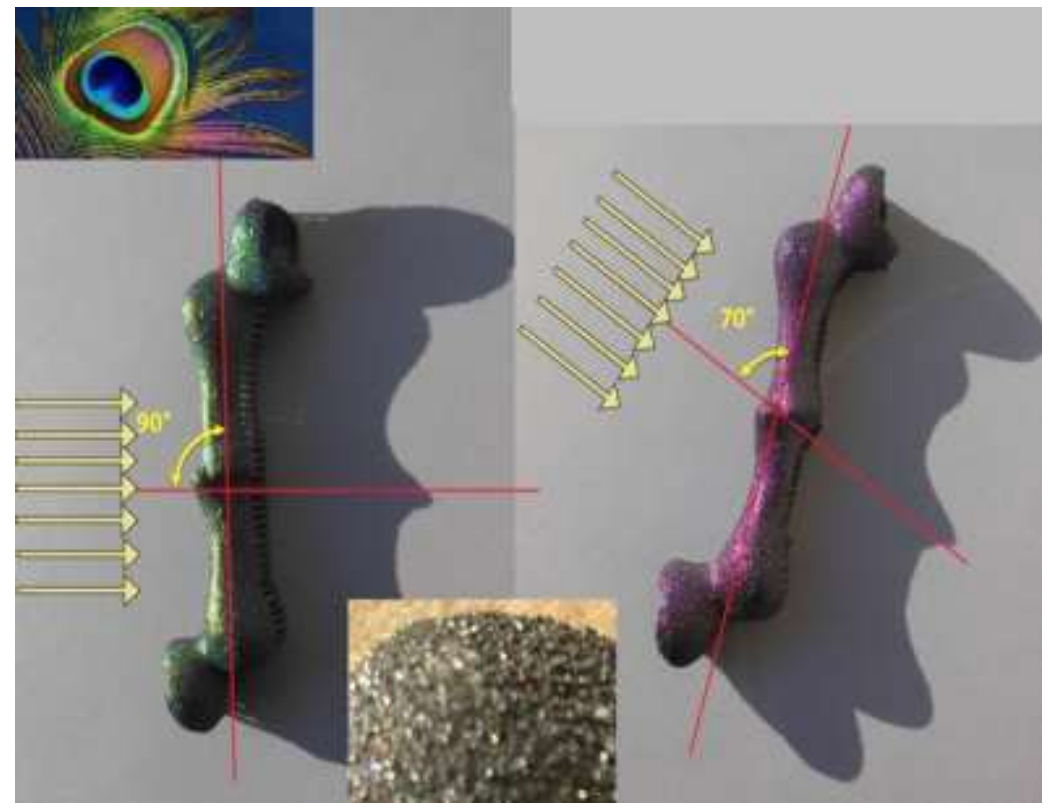

Fig. 8: Iridescence on the IPPA $\mathrm{TiO}_{2}$ coated irregular bumped surface Ti component. Structural colours multiple reflections 

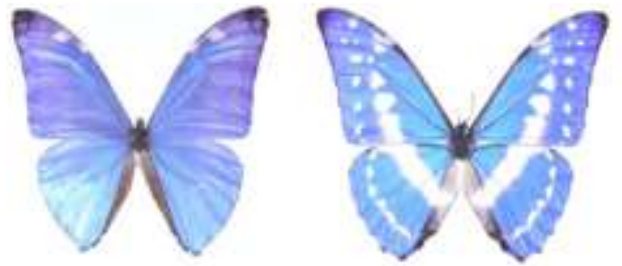

M. adonis

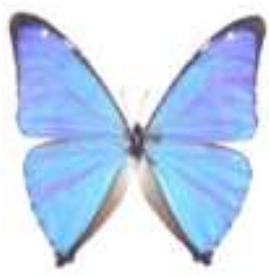

M. aega

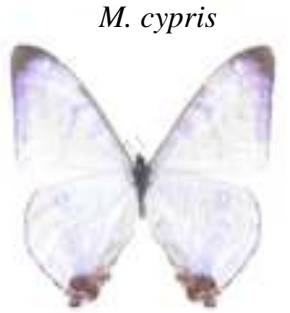

M. sulkowskyi

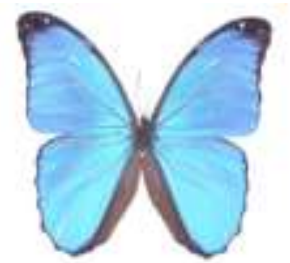

M. menelaus

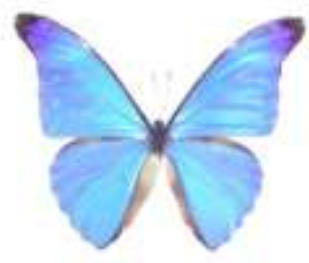

M. rhetenor

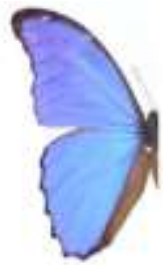

M. didius

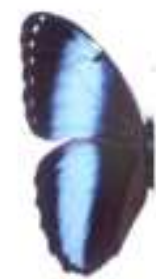

M. achilles

Fig. 9: Typical male Morpho butterflies (Courtesy of the Museum of Nature and Human Activities, Hyogo, Japan) (Kinoshita et al., 2008)

Thus, the so-called Morpho butterflies are those belonging to one the Morpho genus from the Morpho tribe and several dozen species it is now known to exist (Fig. 9) (Kinoshita et al., 2008).

In most Morpho male species, the dorsal wings show a bright blue, but their ventral side is usually dark brown, which reminds us of satirical butterflies. The female is generally less bright or completely shiny. Thus, there are usually three biological explanations for blue colouring the male. One is that the bright blue is intended for mating against a resting woman. Another is to make predatory birds feel dizzy by giving a loud intermittent blink. The third is for territorial purposes against other men because a piece of blue metallic paper is known to attract male Morpho butterflies.

Before continuing in detail, we show the characteristics of the most remarkable one of the Morpho butterfly through simple experiments (Kinoshita et al., 2008):

(1) The first is the dependence of the angle of view of the wing colour. When you see a copy of the Morpho butterfly from above, one actually perceives a bright blue colour, but when the viewing angle is tilted as you hold direction perpendicular to the wing veins, it is observed that the colour does not change at first, but when the angle becomes large sufficiently, the colour of the wing changes rather to violet or dark blue. Instead, if you see the wing keeping the direction parallel to the veins of the wings, the blue colour fades suddenly and the wing turns black Fig. 10e and f. Diploma colour change depends on the species. For example, in Morpho cypris, the colour of the wing changes very quickly to black. Thus one can easily understand the particular characteristic of the structural colour in this butterfly; blue colouration in a wide angular range with a sudden change in violet at large viewing angles and anisotropic reflection dependent on the direction of visualization. All these observations are in contrast to the usual iridescence manufactured animals and goods

(2) The second experiment is performed by immersing the wing in a liquid. Let's use alcohol as a test liquid. Surprisingly, its colour turns green to slightly boring bright and the oblique view looks blue instead of purple (9(a)-(d)). Water use is inadequate, as it does not soak in the wing. The colour change depends on the refractive index of the liquid used. Ethanol has a refractive index of 1,359 . If we use a liquid with a much higher refractive index, such as toluene of 1,497 , then the following happens: The wing changes to dark brown with no gloss. These colour changes are quickly restored when the liquid evaporates. Thus, changing the colour by adding liquid is another typical feature (Kinoshita et al., 2008)

(3) The third experiment consists of observing the wing using a stereo. At a microscope, we can see regularly thin plate rows, as shown in Fig. 11a

These plates are the so-called scales, which are bright blue when the wing is illuminated from above. The blue glow is quite sensitive to the direction of illumination. It just shines when the wing is illuminated from the perpendicular direction at the long axis of the ladder. This experiment is further evidence of the anisotropic reflection described above. The dependence on the lighting direction is strange, why the brightness of the area seems to connect the lines and its position is interchangeable with the lighting direction (Kinoshita et al., 2008). 


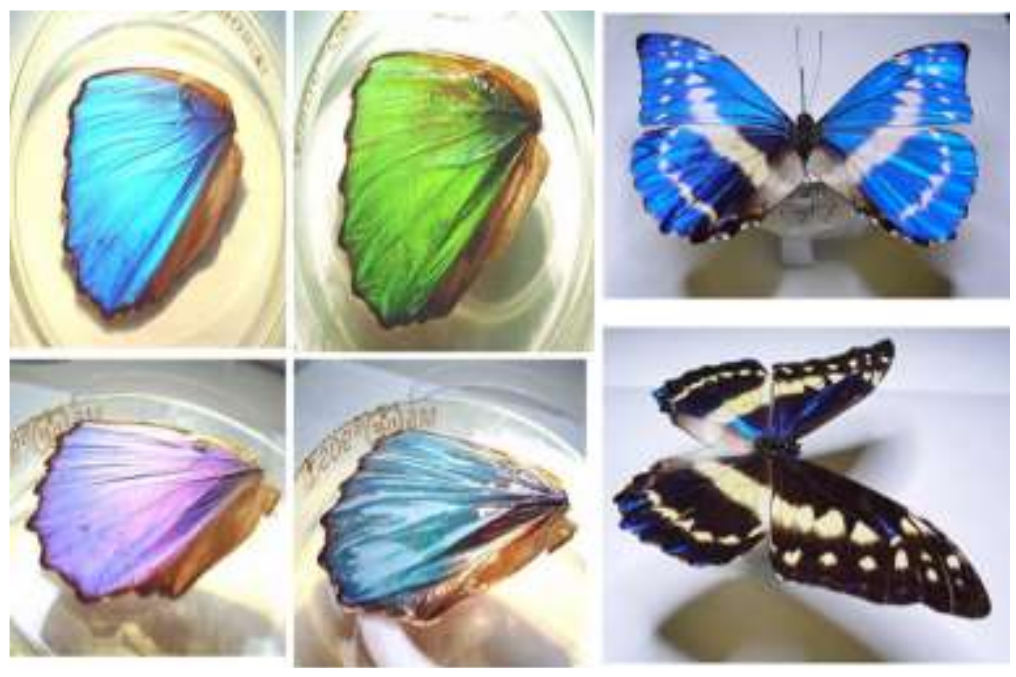

Fig. 10: Frontal and oblique views of the Morpho didius wing (a) and (c) in air and (b) and (d) when immersed into liquid ethanol. Colour change of the Morpho cypris wing observed when the viewing angles are changed, keeping the direction (e) perpendicular and (f) parallel to the wing veins (Kinoshita et al., 2008)
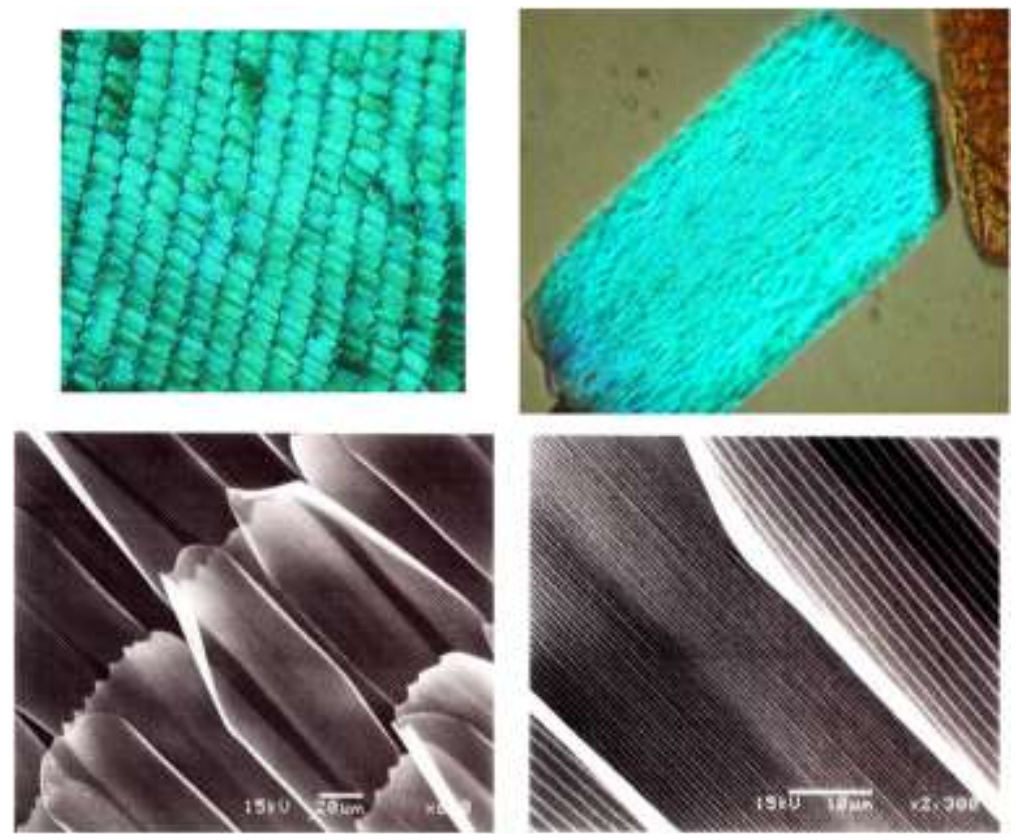

Fig. 11: Optical microscopic images of (a) dorsal wing and (b) scale of $M$. rhetenor observed under epi- and transmitted illumination. (c) and (d) Scanning electron microscopic images of the scales of M. didius [9]

A bird feather consists of a main shaft, from which many barbs branch out. Further, smaller branches called barbules stick out from a barb. The colour of the rock dove's feather is mainly due to numerous sticking barbules, whose length, width and thickness are typically 350,40 and $3 \mu \mathrm{m}$, respectively. The cross-section of a barbule is crescent-shaped, which produces a very broad reflection pattern in one plane under light illumination. It is remarkable that the reflection pattern from a single barbules of a green (purple) feather shows the sudden change from green (purple) to purple (green) with a rather distinctive gray boundary, as shown in Fig. 12a.

It has investigated electron microscopic images of the cross-section of a barbule and has found that a lot of melanin granules are enclosed within a layer of the outer cortex Fig. 12b. The diameters of the melanin granules are randomly distributed from 500 to $750 \mathrm{~nm}$ and their arrangement is also irregular.

Thus they may not contribute directly to the coloration (Kinoshita et al., 2008). 
Peacock (Fig. 13). Photonic crystals are another important source of structural colourations and have been particularly studied in birds and insects. A representative animal possessing this type of structure is the well-known peacock.

The feather of the peacock has been attracting scientific attention for more than 300 years. After the early observations by (Hooke, 2003; Newton, 1952), it was in the 20th century that detailed observations were made by (Mason, 1923). A feather of the peacock consists of many barbs sticking out from the main shaft and each barb has a lot of barbules. The barbules are curved along their long axis and slightly twisted from the roots. Each barbule has the shape of connected segments of a typical size of 20-30 $\mu \mathrm{m}$, the surfaces of which are smoothly curved like a saddle. Mason noticed that liquids with a refractive index between 1.55 and 1.60 destroyed the iridescent colour most effectively. He considered the origin of the structural colouration to be due to the thin colour-producing films of a laminated or plate-like structure. In Fig. 13a-d, we show the barbules observed by SEM. The transverse cross-section of a barbule is crescent-shaped Fig. 13b. Under high magnification, 8-12 layers consisting of periodically arrayed particles are observed beneath the surface layer Fig. 13d, whose diameters are in the range 110-130 nm (Kinoshita et al., 2008).

Over thousands of years of evolution, living organisms have learned ways to manipulate light using delicate and periodically arranged nanostructures. Peacocks, for example, use the structural colours of their feathers as part of mating rituals. Today, these biological models inspire engineers to look for ways to control light through optical technologies. Scientists are working to create reflective screens for e-books or e-paper that no longer need their own light source to read. Such screens would use much less power than the backlit versions of computers, smartphones and TVs. In fact, people have long used structural colour without even being aware of its principle.

The Lycurgus Cup is a Roman artifact housed in the British Museum in London, UK. Made of glass, it changes colour from green to red depending on whether the incident light is reflected by the glass or passes through it. Like peacock feathers, the stunning colour of the Lycurgus glass is due to the structural colour, being caused by small structures of only a few nanometers gold nanoparticles scattered inside the glass. When the surfaces of metal nanoparticles interact with light, they filter/diminish certain colours and favor others. Roman glassmakers found out by chance that the precious metals added to glass give impressive colour effects, but they could not reproduce the effect, so today we have few similar pieces, made around the 4 th century BC.

Today, people can finally use the science of structural colour to make many items, including lipstick in the bag. By using particles made of several thin layers and by immersing them immersed in the formula we obtain an iridescent lipstick. "The regular nanostructures contained in these particles strongly reflect the colours, giving dramatic aspects and selective appearances in different directions."

Researchers are looking to use the physics of light channeling and structural colour in the plastics industry. This is the idea behind Plast4Future, a research project led by Anders Kristensen at the Technical University of Denmark, which focuses on making greener, more pleasing-looking plastics. "Using structural colour, you can get plastic materials that use fewer materials and facilitate recycling in line with the 'swing-in-the-swing' production philosophy," says Kristensen, referring to that approach that shapes the industry based on natural processes that ensure that energy and material resources move from one compartment to another without loss and without the accumulation of waste.

The same physical properties that colour Lycurgus glass will one day colour commercially available plastics. Last year Professor Kristensen developed a way to do this. His team started making a silicon mold with a network of thousands of nano-holes. Then they poured a plastic material into it and deposited a thin film of aluminum on top. The result was a coloured plastic mass without pigments, the colour of which can be adjusted by determining the diameter of those nano-holes (Clausen et al., 2014). "For recycling, the aluminum can be removed from the plastic mass, which can then be melted and remodeled, generating a plastic with the same or a different colour," explains Kristensen. "In the traditional approach, pigments cannot be removed from the material, so recycled plastic will have the same colour," which means that the current recycling of plastic is more inefficient and more complex.

The Plast4Future project is also exploring ways to give plastics other characteristics, such as antifogging or even hydrophobicity (water rejection). All these innovations are of interest to manufacturing companies, from cars to toys: Fiat and LEGO are active partners in this project.

Far from being a curiosity, the structural colour becomes a tool with which we can achieve a cleaner and less polluted world. Such a scenario would have been difficult to imagine by the historical personalities referred to in this story, but they helped us to understand what we know today about this extraordinary source of visual effects. 

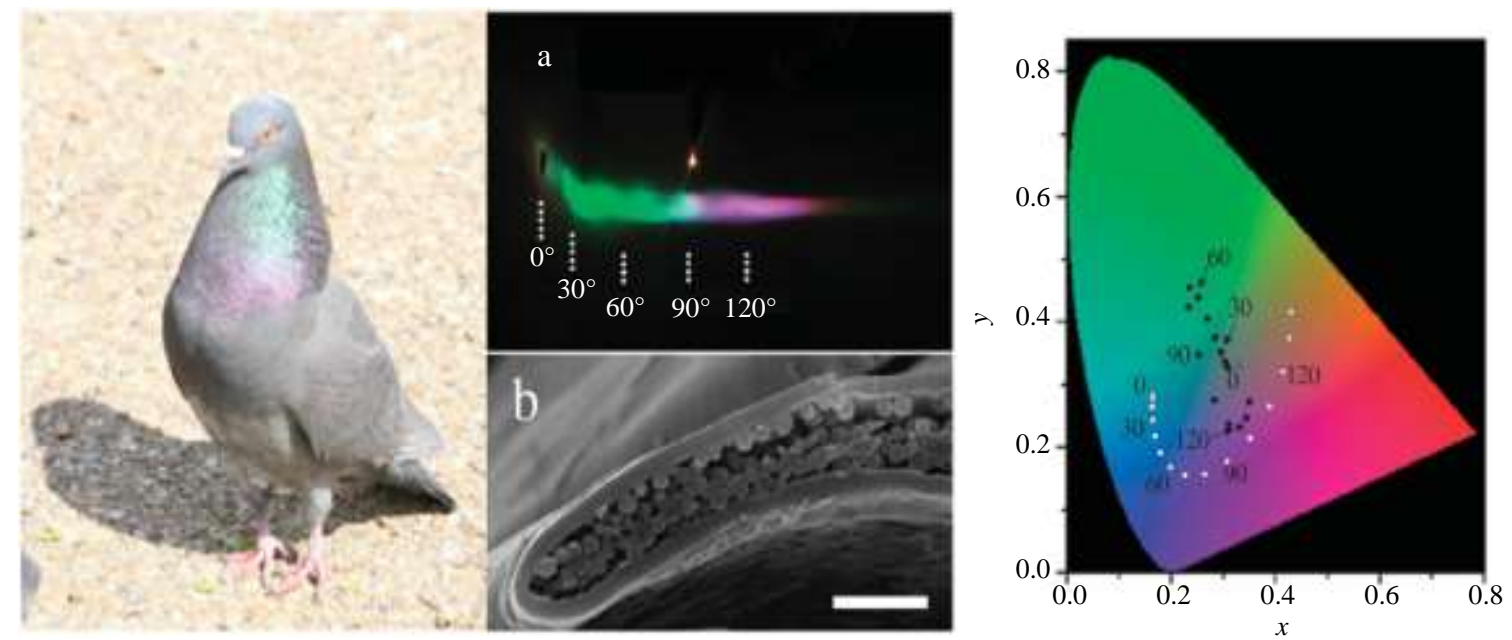

Fig. 12: Rock dove and (a) the reflection pattern of a barbule, where $0 \circ$ indicates the direction of incident white light. (b) SEM image of the cross-sections of the barbule. The right figure indicates the chromaticity diagram showing the loci of the reflection in thin-layer interference at various angles $2 \theta$ for the layer thickness of $650 \mathrm{~nm}$ (closed circle) and $400 \mathrm{~nm}$ (open circle) with the refractive index of 1.5, where $\theta$ is the angle of incidence (Kinoshita et al., 2008)
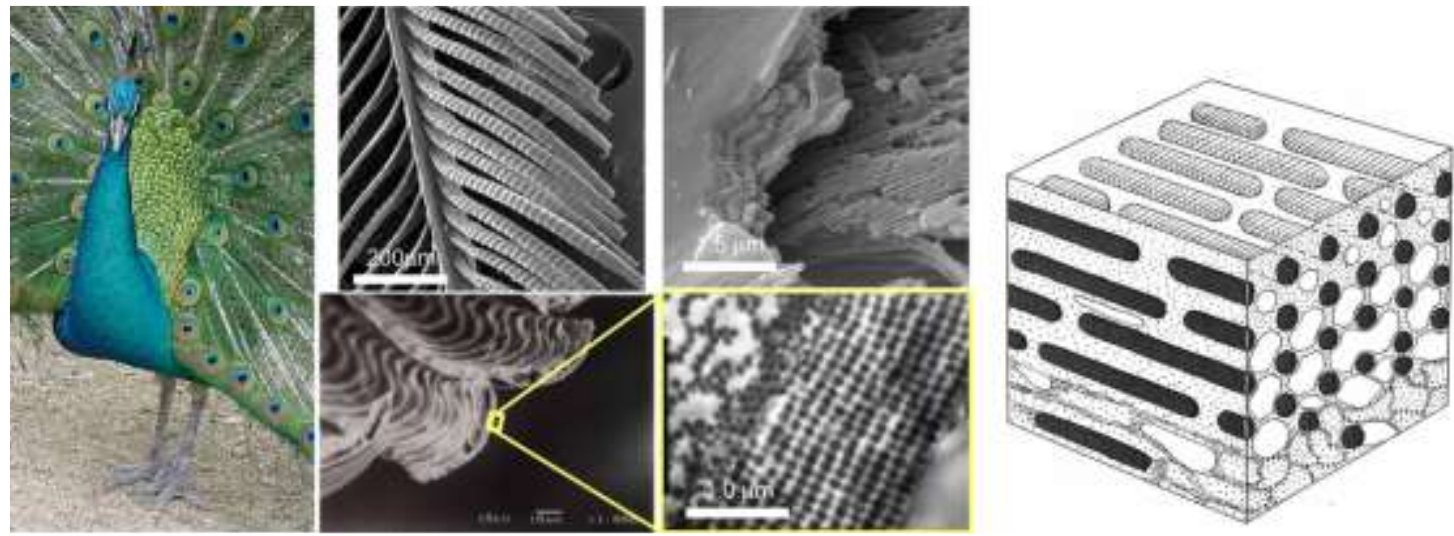

Fig. 13: Peacock (Indian peafowl). SEM images of (a) barbules, (b) the cross-section and (c) interior of a barbule. (d) TEM image of the cross-section of a barbule; (e) Schematic illustration of a 2D photonic crystal in a peacock barbule (Kinoshita et al., 2008)

The European XFEL (X-ray Free-Electron Laser) is a research facility under construction in the Hamburg area of Germany that will help study the basic properties of matter for various disciplines (including nanotechnology) using short X-ray beams. Because the $\mathrm{X}$-ray laser can make structures visible at the atomic scale and time scales by a quarter of a second (10-15) seconds, it will be able to study the details of nanoparticle interactions with other matter and light. This could make it easier for us to understand how nanoparticles are structured, how they behave in terms of reactivity and atomic motion and how they act in different environments, such as solutions or aerosols.

Non-iridescent structural colours, based on the disordered arrangements of monodispersive spherical particles, also called photonic bottles, have a low colour saturation due to the gradual transition in the reflection spectrum. No significant improvement in particle optimization is expected, as Mie resonances are wide for small dielectric particles with a moderate refractive index. Moreover, the short-lived order of the photonic glass is also insufficient to produce sharp spectral characteristics. We show here that the combination of a well-selected particle geometry with the short-lived order of a photonic bottle has strong synergistic effects. Using a first-order approximation and an Ewald sphere construction, the reflection of such structures can be related to the Fourier transform of the permittivity distribution. The required Fourier transform for a highly saturated colour can be achieved by cutting the pattern substructure. We show that this can be achieved by choosing the core-shell particles with a non-monotonous 
distribution of the refractive index from the center of the particle through the shell and in the background material. First-order theoretical predictions are confirmed by numerical simulations.

Structural colour is a colour based on the dispersion and selective reflection of light from nanostructures. The commercial pigment colour derives from the absorption of light by electronic transitions and depends on the presence of a defined chemical structure that can be modified by UV radiation during subsequent use or by processing at high temperatures during manufacture. Also, some of the pigments contain toxic materials that can be harmful to production or disposal, initiating the need for alternatives. At the same time, the structural colours depend only on the distribution of the refractive index and thus can be produced from environmentally friendly materials such as silica, alumina, zirconium, etc. and therefore supports the potential for high UV and temperature stability. Structural colours can be divided into two classes: Iridescent and non-iridescent colours. The iridescent colour is usually based on periodic structures of periodic length, in the order of visible light, known as Photonic Crystals (PhCs).

Non-iridescent structural colours are independent of angle, which means that the colour impression is the same for different angles of illumination and observation. Historically, many research groups have focused on microstructures that mimic biological structures to obtain non-iridescent colours. For example, the feathers of many birds may exhibit bright noniridescent structural colours. The feathers of some birds have structures similar to the compact random arrangements of spherical particles. Such disordered arrangements, also called Photonic bottles (PhG) as opposed to $\mathrm{PhC}$, can be obtained by self-assembling monodisperse spherical particles. Recently, PhGs has attracted a lot of attention in the field of non-iridescent structural colours. The non-iridescent structural colours produced by amorphous structures are mostly shortwavelength colours, such as purple or blue, because the typical band of scattered wavelengths is located at the edge of the sensitivity range of the human eye leading to the impression of a pure blue or purple because the even shorter wavelengths scattered do not contribute to a mixture of colours.

Long-wavelength structural colours longerwavelengths compared to red are difficult to obtain because $\mathrm{PhG}$ structures, in addition, always have a significant dispersion in the short wavelength range. These wavelengths will mix with the intentional red, which spoils the colour impression.

However, colours with longer wavelengths can be produced by introducing a broadband absorber, such as carbon black or others. In particular, they will eliminate shorter scattered wavelengths (blue or green colours), which have spent more time (or more paths) in the disordered environment and are therefore more likely to be absorbed. PhG possesses a short-range order and the Fourier Transform (FT) of its permittivity distribution is a spherical shell. The bright, nonirritating structural colours correlate directly with the spherical shape of the FT shell, such as that observed for the flat-coloured male Cotinga feathers.

However, the reported transition from reflection to reflection regime is still quite smooth, resulting in low colour saturation. An experimental effort was invested in PhG-based structural colours with shell-base particles that led to a marginal spectral improvement only due to the lack of theoretical understanding of the influence of core-shell geometry on colour purity. Most explanations so far are based on a manipulation of Mie resonances in particles. At the same time, small-order Mie resonances in particles with low refractive indices are usually very broad spectra and thus cannot lead to clear transitions in the scattering properties.

Also, small-order Mie resonances of adjacent particles will interact strongly in $\mathrm{PhG}$, which is difficult to consider. To the best of our knowledge, for the first time, we offer a comprehensive theoretical and simulator treatment of structural colours using photonic glasses based on first-order approximation. It helps to explain the main mechanisms of colour generation and provides a clear design and synthesis rules to achieve high colour saturation.

In biology, chitin $\left(\mathrm{C}_{8} \mathrm{H}_{13} \mathrm{NO}_{5}\right)_{\mathrm{n}}$ is a polysaccharide, a cellulose-like organic substance that forms the exoskeleton of insects or other arthropods (crustaceans or arachnids). It is also found in other kingdoms, such as lichens or certain species of fungi. For example, the shell of a crab contains $25 \%$ chitin and $75 \%$ calcium carbonate.

In 1821 the Frenchman Henri Bracon (Braconnot), the director of the Nancy Botanical Garden, found in mushrooms a substance insoluble in sulfuric acid, which he called a fungus. Chitin was first isolated from the tarantula shell. The term chitin was proposed by the French scientist A. Odio in 1823 while investigating the carapace of insects.

It is a modified sugar containing nitrogen, a polysaccharide, from the acetylglucosamine (N-acetylglucosamine) group linked together by a $\beta-1,4$ covalent bond (similar to the bonds between glucose groups in cellulose molecules). Thus chitin can be described as cellulose with a hydroxyl group of each monomer replaced with an acetyl amine group. This formula allows closer bonds between the hydrogen atoms of the adjacent polymers, resulting in a stronger material. The chemical name of the molecule is poly $\mathrm{N}$ acetyl D glucosamine, $\beta-(1,4)$-2-Acetamido-2deoxy-D-glucose, or simply $\mathrm{N}$-acetyl-D-glucosamine $\beta$ - $(1,4) \mathrm{N}$-acetyl- D-glucosamine. 
In pure form, chitin is translucent, foldable, durable and hard. In arthropods it is often modified, being incorporated into a hard protein matrix that forms the exoskeleton. In its pure form, it has a skin texture and consistency but combined with calcium carbonate, it becomes much more resistant. The difference between the modified and the unmodified form can be seen by comparing a caterpillar (unmodified) with a beetle (modified). Although it is translucent, different sizes of parallel microfiber layers can create structural colours due to the interference phenomenon.

Chitin is present in the exoskeleton of Cambrian arthropods, such as trilobites. The oldest sample of chitin dates back to the Oligocene, 25 million years ago.

Chitin is one of the constituents of the cuticle in insects, spiders or crustaceans and has a protective role. Combined with calcium carbonate it becomes rigid and forms the exoskeleton of crustaceans, for example, snails. The chitin found in the arthropod cuticle is chitin alpha, in which the chains of chitin molecules are aligned in an antiparallel manner by hydrogen bonds. In brachiopods, cephalopods and annelids, chitin beta is found where the chains of molecules are aligned in parallel. Chitin gamma is rarer in brachiopods. In fungi, chitin is an essential component of the sidewall and protects fungal cells from the environment. Chitin actively participates in the rigidity of the fungal wall. The chitin polymer of biological origin is synthesized by an enzymatic activity called chitin synthesis. In Saccharomyces cerevisiae, several chitin synthesis activities take place in different intracellular locations and at certain stages of budding of this unicellular fungus.

This organic component is generally well supported by biological tissues and is used in cosmetics or in the treatment of burns. In surgery, it is used as a surgical thread, due to its strength, flexibility and the fact that it is biodegradable, resorbing as the wound heals. It appears to have properties that accelerate wound healing in humans.

Occupations associated with high levels of chitin, such as shellfish preparation, are prone to high rates of asthma. Recent studies show that chitin may play a role in the introduction of allergies in humans. Mice treated with chitin develop an allergen response, characterized by increased interleukin- 4 protein in the cells of the immune system. For these mice, additional treatment with the chitin enzyme cancels out the response.

Chitin is also used to filter wastewater: It makes chains to which ionizable elements of organic matter are attached (see chitosan). It is used in the food industry to make juices.

Recent studies show that chitin induces an increase in the effectiveness of plant defense mechanisms. It is also mentioned as a fertilizer that can improve production. Chitosan is derived from chitin and is used as a biocontrol element in agriculture and horticulture.

Chitin is used in industry in many processes. It is used as an additive to stabilize and give consistency to foods or pharmaceuticals. It also acts as a binder in paints, textiles, or adhesives. Separation membranes and ion-exchange resins can be produced from chitin.

Chitin is the second polymer produced in the world after cellulose. It is produced from marine crustaceans and the production is estimated at $2.3 \times 10^{9} \mathrm{t}$.

\section{Conclusion}

Due to recent advances in plasma deposition technology, it has been possible to define an innovative treatment for biomedical applications and for the conservation and protection of old residues of $\mathrm{SiO}_{2}$ and $\mathrm{TiO}_{2}$ deposited through the IPPA process.

Plasma ionic nano-film (IPPA) storage of $\mathrm{TiO}_{2}$ and $\mathrm{SiO}_{2}$ could preferentially induce a wide range of surface effects, from structural staining to transparent or superhydrophobic achromatic coating, depending on the surface characteristics of the deposited material and surface morphologies of the substrate.

Such treatment can be useful in many areas, including in biomedical applications, as well as in cosmetic dental surgery or in relic preservation.

The presence of the coating treatment inside the pores could guarantee even more effective protection for the penetration of liquid water into the porosity of the ceramic plate, reducing the risk of unwanted growth of the fungi or mold.

However, the outer surface maintains a good humidity required for the cleaning operation (the wet surface will not appear "oily").

The same technology has been shown to be capable of inducing very strong structural effects of colour and iridescence.

It was confirmed by our investigation of the structural colours obtained by $\mathrm{TiO} 2$ coating, that multiple reflections in regular or irregular surface morphology, as described by (Kinoshita and Yoshioka, 2005), may create colour enhancement or cancellation effects.

In particular, it has been demonstrated experimentally that the presence of an irregularly shaped surface (such as those obtained by the manufacture of additives) could increase the generation of structural colours.

\section{Acknowledgement}

The authors acknowledge Dr. Francesco Tatti (FEI Company Application Specialist SEM-SDB) for its contribution to the preparation of SEM analyses. 


\section{Funding Information}

Research contract: Contract number 36-5-4D/1986 from 24IV1985, beneficiary CNST RO (Romanian National Center for Science and Technology) Improving dynamic mechanisms internal combustion engines. All these matters are copyrighted. Copyrights: 548cgiywDssin, from: 22-04-2010, 08:48:48.

\section{Author's Contributions}

All authors equally contributed in this work.

\section{Ethics}

Author declares that are not ethical issues that may arise after the publication of this manuscript. This article is original and contains unpublished material.

\section{References}

Abam, F. I., Ugot, I. U., \& Igbong, D. I. (2012). Performance analysis and components irreversiblities of a (25 MW) gas turbine power plant modeled with a spray cooler. American Journal of Engineering and Applied Sciences, 5(1), 35-41.

Abdelkrim, H., Othman, S. B., Salem, A. K. B., \& Saoud, S. B. (2012). Dynamic partial reconfiguration contribution on system on programmable chip architecture for motor drive implementation. Am. J. Eng. Applied Sci, 5, 15-24.

Abdullah, H., \& Halim, S. A. (2009). Electrical and Magnetoresistive studies Nd doped on La-Ba-Mn-O sub (3) Manganites for Lowfield Sensor application. American Journal of Engineering and Applied Sciences, 2(2).

Abdullah, M. Z., Saat, A., \& Hamzah, Z. (2011). Optimization of energy dispersive $\mathrm{x}$-ray fluorescence spectrometer to analyze heavy metals in moss samples. American Journal of Engineering and Applied Sciences, 4(3).

Abdullah, M. Zain, A. F. M. Ho, Y. H., \& Abdullah, S. (2009). TEC and Scintillation Study of Equatorial Ionosphere: A Month Campaign over Sipitang and Parit Raja Stations, Malaysia, Am. J. Eng. Applied Sci. 2(1):44-49.

Abou Jaoude, A., \& El-Tawil, K. (2013). Analytic and nonlinear prognostic for vehicle suspension systems. American Journal of Engineering and Applied Sciences, 6(1), 42-56.

Abouobaida, H. (2016). Robust and efficient controller to design a standalone source supplied DC and AC load powered by photovoltaic generator. Am. J. Eng. Applied Sci, 9, 894-901.
Ab-Rahman, M. S., Guna, H., Harun, M. H., Zan, S. D., \& Jumari, K. (2009). Cost-effective fabrication of self-made $1 \times 12$ polymer optical fiber-based optical splitters for automotive application. Am. J. Eng. Applied Sci, 2, 252-259.

Abu-Ein, S. (2009). Numerical and analytical study of exhaust gases flow in porous media with applications to diesel particulate filters. Am. J. Eng. Applied Sci, 2, 70-75.

Abu-Lebdeh, T. M., Leon, G. P. D., Hamoush, S. A., Seals, R. D., \& Lamberti, V. E. (2016). Gas atomization of molten metal: Part II. Applications. American Journal of Engineering and Applied Sciences, 9(2).

Agarwala, S. (2016). A perspective on 3D bioprinting technology: Present and future. Am. J. Eng. Applied Sci, 9, 985-990.

Ahmed, M., Khan, R., Billah, M., \& Farhana, S. (2010). A novel navigation algorithm for hexagonal hexapod robot. Am. J. Eng. Applied Sci, 3, 320-327.

Ahmed, R., Khan, M., Haque, H., \& Rahman, H. (2016). An approach to develop a dynamic job shop scheduling by fuzzy rule-based system and comparative study with the traditional priority rules. Am. J. Eng. Applied Sci, 9, 202-212.

Akhesmeh, S., Pourmahmoud, N., \& Sedgi, H. (2008). Numerical study of the temperature separation in the Ranque-Hilsch vortex tube. American Journal of Engineering and Applied Sciences, 1(3).

Al Dharrab, A. Zafa, M. Khan, E. Aversa, R. Petrescu, R. V. Apicella, A., \& Petrescu, F. I. T. (2017). Influence of Curing Light Type and Staining Medium on the Discoloring Stability of Dental Restorative Composite (November 29, 2017). American Journal of Biochemistry and Biotechnology, Volume 13, Issue 1, Pages 42-50.

Al Madani, D., \& Dababneh, A. (2016). Rapid entire body assessment: A literature review. American Journal of Engineering and Applied Sciences, 9(1), 107-118.

Al Qadi, A. N. S., ALhasanat, M. B., Dahamsheh, A. A., \& Zaiydneen, S. A. (2016a). Using of box-benken method to predict the compressive strength of selfcompacting concrete containing Wadi Musa bentonite, Jordan. Am. J. Eng. Applied Sci, 9, 406-411.

Al Qadi, A. N., Alhasanat, M. B., \& Haddad, M. (2016b). Effect of crumb rubber as coarse and fine aggregates on the properties of asphalt concrete. Am. J. Eng. Applied Sci, 9, 558-564.

Al Smadi, T. A. (2011). Low cost smart sensor design. Am. J. Eng. Applied Sci, 4, 162-168.

Al-Abbas, I. K. (2009). Reduced order models of a current source inverter induction motor drive. Am. J. Eng. Applied Sci, 2, 39-43. 
Ale Ebrahim, N., Ahmed, S., Abdul Rashid, S. H., \& Taha, Z. (2012). Technology use in the virtual R\&D teams. American Journal of Engineering and Applied Sciences, 5(1), 9-14.

Aleksic, S., \& Lovric, A. (2011). Energy consumption and environmental implications of wired access networks. Am. J. Eng. Applied Sci, 4, 531-539.

Al-Hasan, M. I., \& Al-Ghamdi, A. S. (2016). Energy balance for a diesel engine operates on a pure biodiesel, diesel fuel and biodiesel-diesel blends. Am. J. Eng. Applied Sci, 9, 458-465.

Alhasanat, M. B., Al Qadi, A. N., Al Khashman, O. A., \& Dahamsheh, A. (2016). Scanning electron microscopic evaluation of self-compacting concrete spalling at elevated temperatures. Am. J. Eng. Applied Sci, 9, 119-127.

Ali, G. A. M., Fouad, O., \& Makhlouf, S. A. (2016). Electrical properties of cobalt oxide/silica nanocomposites obtained by sol-gel technique. Am. J. Eng. Applied Sci, 9, 12-16.

Ali, K. S., \& Shumaker, J. L. (2013). Hardware in the loop simulator for multi agent unmanned aerial vehicles environment. American Journal of Engineering and Applied Sciences, 6(2), 172.

Alwetaishi, M. S. (2016). Impact of building function on thermal comfort: A review paper. Am. J. Eng. Applied Sci, 9, 928-945.

Aly, W. M., \& Abuelnasr, M. S. (2010). Electronic design automation using object oriented electronics. American Journal of Engineering and Applied Sciences, 3(1).

Amani, N. (2016). Design and implementation of optimum management system using cost evaluation and financial analysis for prevention of building failure. Am. J. Eng. Applied Sci, 9, 281-296.

Anizan, S., Yusri, K., Leong, C. S., Amin, N., Zaidi, S., \& Sopian, K. (2011). Effects of the contact resistivity variations of the screen-printed silicon solar cell. Am. J. Eng. Applied Sci, 4, 328-331.

Aronov, D., Rosenman, G., \& Barkay, Z. (2007). Wettability study of modified silicon dioxide surface using environmental scanning electron microscopy. Journal of applied physics, 101(8), 084901.

Ascione, F., Bianco, N., De Masi, R. F., De Rossi, F., De Stasio, C., \& Vanoli, G. P. (2016). Energy audit of health care facilities: Dynamic simulation of energy performances and energy-oriented refurbishment of system and equipment for microclimatic control.

Augustine, A., Prakash, R. D., Xavier, R., \& Parassery, M. C. (2016). Review of signal processing techniques for detection of power quality events. Am. J. Eng. Applied Sci, 9, 364-370.
Aversa, R., Buzea, E. M., Petrescu, R. V., Apicella, A., Neacsa, M., \& Petrescu, F. I. (2016e). Present a mechatronic system having able to determine the concentration of carotenoids. American Journal of Engineering and Applied Sciences, 9(4), 1106-1111.

Aversa, R., Parcesepe, D., Petrescu, R. V. V., Chen, G., Petrescu, F. I. T., Tamburrino, F., \& Apicella, A. (2016b). Glassy amorphous metal injection molded induced morphological defects.

Aversa, R., Parcesepe, D., Petrescu, R. V., Berto, F., Chen, G., Petrescu, F. I.,... \& Apicella, A. (2017b). Process ability of bulk metallic glasses. American Journal of Applied Sciences, 14(2), 294-301.

Aversa, R., Perrotta, V., Petrescu, R. V., Carlo, M., Petrescu, F. I., \& Apicella, A. (2016g). From structural colours to super-hydrophobicity and achromatic transparent protective coatings: Ion plating plasma assisted $\mathrm{TiO}_{2}$ and $\mathrm{SiO}_{2}$ nano-film deposition. Available at SSRN 3074477.

Aversa, R., Petrescu, F. I., Petrescu, R. V., \& Apicella, A. (2016a). Biomimetic finite element analysis bone modeling for customized hybrid biological prostheses development. American Journal of Applied Sciences, 13(11), 1060-1067.

Aversa, R., Petrescu, F. I., Petrescu, R. V., \& Apicella, A. (2016o). Flexible stem trabecular prostheses. American Journal of Engineering and Applied Sciences, 9(4).

Aversa, R., Petrescu, R. V., Apicella, A., \& Petrescu, F. I. (2017a). Nano-diamond hybrid materials for structural biomedical application. American Journal of Biochemistry and Biotechnology, 13(1), 34-41.

Aversa, R., Petrescu, R. V., Apicella, A., \& Petrescu, F. I. (2016i). Mitochondria are naturally micro robots-a review. American Journal of Engineering and Applied Sciences, 9(4).

Aversa, R., Petrescu, R. V., Apicella, A., \& Petrescu, F. I. (2016j). We are addicted to vitamins C and E-A review. American Journal of Engineering and Applied Sciences, 9(4), 1003-1018.

Aversa, R., Petrescu, R. V., Apicella, A., \& Petrescu, F. I. (2016k). Physiologic human fluids and swelling behavior of hydrophilic biocompatible hybrid ceramo-polymeric materials. American Journal of Engineering and Applied Sciences, 9(4), 962-972.

Aversa, R., Petrescu, R. V., Apicella, A., \& Petrescu, F. I. (20161). One can slow down the aging through antioxidants. American Journal of Engineering and Applied Sciences, 9(4).

Aversa, R., Petrescu, R. V., Apicella, A., \& Petrescu, F. I. $(2016 \mathrm{~m})$. About homeopathy or «Similia similibus curentur $\gg$. American Journal of Engineering and Applied Sciences, 9(4).

Aversa, R., Petrescu, R. V., Apicella, A., \& Petrescu, F. I. (2016n). The basic elements of life's. American Journal of Engineering and Applied Sciences, 9(4), 1189-1197. 
Aversa, R., Petrescu, R. V., Petrescu, F. I., \& Apicella, A. (2016c). Smart-factory: Optimization and process control of composite centrifuged pipes. American Journal of Applied Sciences, 13(11), 1330-1341.

Aversa, R., Petrescu, R. V., Petrescu, F. I., \& Apicella, A. (2016h). Biomimetic and evolutionary design driven innovation in sustainable products development. American Journal of Engineering and Applied Sciences, 9(4).

Aversa, R., Petrescu, R. V., Sorrentino, R., Petrescu, F. I., \& Apicella, A. (2016f). Hybrid ceramo-polymeric nanocomposite for biomimetic scaffolds design and preparation. American Journal of Engineering and Applied Sciences, 9(4).

Aversa, R., Tamburrino, F., Petrescu, R. V., Petrescu, F. I., Artur, M., Chen, G., \& Apicella, A. (2016d). Biomechanically inspired shape memory effect machines driven by muscle like acting NiTi alloys. American Journal of Applied Sciences, 13(11), 1264-1271.

Babayemi, A. K. (2016). Thermodynamics, non-linear isotherms, statistical modeling and optimization of phosphorus adsorption from wastewater. Am. J. Eng. Applied Sci, 9, 1019-1026.

Bakar, R. A., Mohammed, M. K., \& Rahman, M. M. (2009). Numerical study on the performance characteristics of hydrogen fueled port injection internal combustion engine. Am. J. Eng. Applied Sci, 2, 407-415.

Barone, G., Buonomano, A., Forzano, C., \& Palombo, A. (2016). WLHP systems in commercial buildings: A case study analysis based on a dynamic simulation approach. Am. J. Eng. Applied Sci, 9, 659-668.

Bedon, C. (2016). Review on the use of FRP composites for facades and building skins.

Bedon, C., \& Amadio, C. (2016). A unified approach for the shear buckling design of structural glass walls with non-ideal restraints. Am. J. Eng. Applied Sci, 9, 64-78.

Bedon, C., \& Louter, C. (2016). Finite-element numerical simulation of the bending performance of post-tensioned structural glass beams with adhesively bonded cfrp tendons.

Bolonkin, A. (2009a). Femtotechnology: Nuclear matter with fantastic properties. Am. J. Eng. Applied Sci, 2(2), 501-514.

Bolonkin, A. (2009b). Converting of matter to nuclear energy by ab-generator. Am. J. Eng. Applied Sci, 2, 683-693.

Boucetta, A. (2008). Vector control of a variable reluctance machine stator and rotor discs imbricates. American Journal of Engineering and Applied Sciences, 1(4).
Bucinell, R. B. (2016). Stochastic model for variable amplitude fatigue induced delamination growth in graphite/epoxy laminates. Am. J. Eng. Applied Sci, 9, 635-646.

Budak, S., Xiao, Z., Johnson, B., Cole, J., Drabo, M., Tramble, A., \& Casselberry, C. (2016). High Efficient Advanced Thermoelectric Devices from Different Multilayer Thin Films.

Buonomano, A., Calise, F., \& Vicidomini, M. (2016a). A novel prototype of a small-scale solar power plant: Dynamic simulation and thermoeconomic analysis. Am. J. Eng. Applied Sci, 9, 770-788.

Buonomano, A., Calise, F., d'Accadia, M. D., Vanoli, R., \& Vicidomini, M. (2016b). Simulation and experimental analysis of a demonstrative solar heating and cooling plant installed in Naples (Italy). Am. J. Eng. Applied Sci, 9, 798-813.

Calise, F., Dâ'Accadia, M. D., Libertini, L., Quiriti, E., \& Vicidomini, M. (2016). Dynamic simulation and optimum operation strategy of a trigeneration system serving a hospital. Am. J. Eng. Applied Sci, 9, 854-867.

Campo, T., Cotto, M., Márquez, F., Elizalde, E., \& Morant, C. (2016). Graphene Synthesis by PlasmaEnhanced CVD Growth with Ethanol. American Journal of Engineering and Applied Sciences, 9(3).

Cardu, M., Oreste, P., \& Cicala, T. (2009). Analysis of the tunnel boring machine advancement on the Bologna-Florence railway link. Am. J. Eng. Applied Sci, 2, 416-420.

Chen, G., \& Xu, L. (2016). A general strategy to enhance up conversion luminescence in rare-earthion-doped oxide nanocrystals. Am. J. Eng. Applied Sci, 9, 79-83.

Chiozzi, A., Milani, G., Grillanda, N., \& Tralli, A. (2016). An adaptive procedure for the limit analysis of FRP reinforced masonry vaults and applications.

Chisari, C., \& Bedon, C. (2016). Multi-objective optimization of FRP jackets for improving the seismic response of reinforced concrete frames.

Chrystal, J. C. (1873). A treatise on electricity and magnetism (Vol. 1). Clarendon press.

Clausen, J. S., Højlund-Nielsen, E., Christiansen, A. B., Yazdi, S., Grajower, M., Taha, H.,... \& Mortensen, N. A. (2014). Plasmonic metasurfaces for coloration of plastic consumer products. Nano letters, 14(8), 4499-4504.

Darabi, A., Soleamani, S. A., \& Hassannia, A. (2008). Fuzzy based digital automatic voltage regulator of a synchronous generator with unbalanced loads. American J. of Engineering and Applied Sciences, 1(4), 280-286.

Daud, H., Yahya, N., Aziz, A. A., \& Jusoh, M. F. (2008). Development of wireless electric concept powering electrical appliances. Am. J. Eng. Applied Sci, 1, 12-15. 
Djalel, D., Mourad, M., \& Labar, H. (2013). New approach of electromagnetic fields of the lightning discharge. Am. J. Eng. Applied Sci, 6, 369-383.

Dos Santos, F. A., \& Bedon, C. (2016). Preliminary experimental and finite-element numerical assessment of the structural performance of SMAreinforced GFRP systems. American Journal of Engineering and Applied Sciences, 9(3), 692-701.

El-Labban, H. F., Abdelaziz, M., \& Mahmoud, E. R. (2013). Modification of carbon steel by laser surface melting: Part I: Effect of laser beam travelling speed on microstructural features and surface hardness. Am. J. Eng. Applied Sci, 6, 352-359.

Elliott, A., AlSalihi, S., Merriman, A. L., \& Basti, M. M. (2016). Infiltration of nanoparticles into porous binder jet printed parts. American Journal of Engineering and Applied Sciences, 9(1).

Elmeddahi, Y., Mahmoudi, H., Issaadi, A., Goosen, M. F., \& Ragab, R. (2016). Evaluating the effects of climate change and variability on water resources: A case study of the cheliff Basin in Algeria. American Journal of Engineering and Applied Sciences, 9(4), 835-845.

El-Tous, Y. (2008). Pitch angle control of variable speed wind turbine. American Journal of Engineering and Applied Sciences, 1(2), 118-120.

Faizal, A., Mulyono, S., Yendra, R., \& Fudholi, A. (2016). Design Maximum Power Point Tracking (MPPT) on photovoltaic panels using fuzzy logic method. Am. J. Eng. Applied Sci, 9, 789-797.

Farahani, A. S., Adam, N. M., \& Ariffin, M. K. A. (2010). Simulation of airflow and aerodynamic forces acting on a rotating turbine ventilator. Am. J. Eng. Applied Sci, 3, 159-170.

Fathallah, A. Z. M., \& Bakar, R. A. (2009). Prediction studies for the performance of a single cylinder high speed spark ignition linier engine with spring mechanism as return cycle. American Journal of Engineering and Applied Sciences, 2(4).

Fen, Y. W., \& Yunus, W. (2011). Optical properties of crosslinked chitosan thin film with glutaraldehyde using surface plasmon resonance technique. American Journal of Engineering and Applied Sciences, 4(1).

Feraga, C. E., Moussaoui, A., Bouldjedri, A., \& Yousfi, A. (2009). Robust position controller for a permanent magnet synchronous actuator. American Journal of Engineering and Applied Sciences, 2(2).

Gusti, A. P. Semin, 2016. The effect of vessel speed on fuel consumption and exhaust gas emissions. Am. J. Eng. Applied Sci, 9, 1046-1053.

Hasan, S., \& El-Naas, M. H. (2016). Optimization of a combined approach for the treatment of carbide slurry and capture of CO2. Am. J. Eng. Applied Sci, 9, 449-457.
Hassan, M., Mahjoub, H., \& Obed, M. (2012). Voicebased control of a DC servo motor. American Journal of Engineering and Applied Sciences, 5(1).

Helmy, A. K., \& El-Taweel, G. S. (2010). Neural network change detection model for satellite images using textural and spectral characteristics. American Journal of Engineering and Applied Sciences, 3(4).

Hertz, (1884), Wiedemann Annalen 23 84-103.

Hirun, W. (2016). Evaluation of interregional freight generation modelling methods by using nationwide commodity flow survey data. Am. J. Eng. Applied Sci, 9, 625-634.

Ho, C. Y. F., Ling, B. W. K., Giovanni, B. S., Chi, Z. W., \& Siu, W. C. (2011, July). Single step optimal block matched motion estimation with motion vectors having arbitrary pixel precisions. In 2010 7 th International Symposium on Communication Systems, Networks \& Digital Signal Processing (CSNDSP 2010) (pp. 316-326). IEEE.

Hooke, R. (2003). Micrographia: Or some physiological descriptions of minute bodies made by magnifying glasses, with observations and inquiries thereupon. Courier Corporation.

Huang, B., Masood, S. H., Nikzad, M., Venugopal, P. R., \& Arivazhagan, A. (2016). Dynamic mechanical properties of fused deposition modelling processed polyphenylsulfone material. Am. J. Eng. Applied Sci, 9, 1-11.

Idarwazeh, S. (2011). Inverse Discrete Fourier Transform-Discrete Fourier Transform Techniques for Generating and Receiving Spectrally Efficient Frequency Division Multiplexing Signals, Am. J. Eng. Applied Sci. 4(4):598-606.

Iqbal, M. (2016). An overview of Energy Loss Reduction (ELR) software used in Pakistan by WAPDA for calculating transformer overloading, line losses and energy losses. Am. J. Eng. Applied Sci, 9, 442-448.

Ismail, M. I. S., Okamoto, Y., Okada, A., \& Uno, Y. (2011). Experimental investigation on microwelding of thin stainless steel sheet by fiber laser. Am. J. Eng. Applied Sci, 4, 314-320.

Jaber, A. A., \& Bicker, R. (2016). Industrial robot fault detection based on statistical control chart. Am. J. Eng. Applied Sci, 9, 251-263.

Jafari, N., Alsadoon, A., Withana, C. P., Beg, A., \& Elchouemi, A. (2016). Designing a comprehensive security framework for smartphones and mobile devices. American Journal of Engineering and Applied Sciences, 9(3), 724-734.

Jalil, M. I., \& Sampe, J. (2013). Experimental investigation of thermoelectric generator modules with different technique of cooling system. American Journal of Engineering and Applied Sciences, 6(1), 1-7. 
Jarahi, H. (2016). Probabilistic seismic hazard deaggregation for Karaj City (Iran). Am. J. Eng. Applied Sci, 9, 520-529.

Jarahi, H., \& Seifilaleh, S. (2016). Rock fall hazard zonation in Haraz Highway. Am. J. Eng. Applied Sci, 9, 371-379.

Jauhari, K., Widodo, A., \& Haryanto, I. (2016). Identification of a machine tool spindle critical frequency through modal and imbalance response analysis. Am. J. Eng. Applied Sci, 9, 213-221.

Jiang, J., Chen, Q., \& Nimbalkar, S. (2016). Field data based method for predicting long-term settlements.

Kaewnai, S., \& Wongwises, S. (2011). Improvement of the runner design of francis turbine using computational fluid dynamics. Am. J. Eng. Applied Sci, 4, 540-547.

Kamble, V. G., \& Kumar, N. (2016). Fabrication and tensile property analysis of polymer matrix composites of graphite and silicon carbide as fillers. Am. J. Eng. Applied Sci, 9, 17-30.

Kazakov, V. V., Pavlikov, A. I., Kamensky, V. A., Yusupov, V. I., \& Bagratashvili, V. N. (2016). Control of bubble formation at the optical fiber tip by analyzing ultrasound acoustic waves. American Journal of Engineering and Applied Sciences, 9(4), 921-927.

Kechiche, O. B. H. B., Sethom, H. B. A., Sammoud, H., \& Belkhodja, I. S. (2011). Optimized high frequency signal injection based permanent magnet synchronous motor rotor position estimation applied to washing machines. American Journal of Engineering and Applied Sciences, 4(3).

Kinoshita, S. Yoshioka, S., \& Miyazaki, J. (2008). Physics of structural colours. Rep. Prog. Phys, 71(076), 401

Kinoshita, S., \& Yoshioka, S. (2005). Structural colours in nature: The role of regularity and irregularity in the structure. ChemPhysChem, 6(8), 1442-1459.

Kinoshita, S., Yoshioka, S., \& Kawagoe, K. (2002). Mechanisms of structural colour in the Morpho butterfly: Cooperation of regularity and irregularity in an iridescent scale. Proceedings of the Royal Society of London. Series B: Biological Sciences, 269(1499), 1417-1421.

Kuli, I., Abu-Lebdeh, T. M., Fini, E. H., \& Hamoush, S. A. (2016). The use of nano-silica for improving mechanical properties of hardened cement paste. Am. J. Eng. Applied Sci, 9, 146-154.

Kunanoppadon, J. (2010). Thermal efficiency of a combined turbocharger set with gasoline engine. Am. J. Eng. Applied Sci, 3, 342-349.

Kwok, D. Y., Gietzelt, T., Grundke, K., Jacobasch, H. J., \& Neumann, A. W. (1997). Contact angle measurements and contact angle interpretation. 1. Contact angle measurements by axisymmetric drop shape analysis and a goniometer sessile drop technique. Langmuir, 13(10), 2880-2894.
Kwon, S., Tani, Y., Okubo, H., \& Shimomura, T. (2010). Fixed-star tracking attitude control of spacecraft using single-gimbal control moment gyros. Am. J. Eng. Applied Sci, 3, 49-55.

Lamarre, A., Fini, E. H., \& Abu-Lebdeh, T. M. (2016). Investigating effects of water conditioning on the adhesion properties of crack sealant. Am. J. Eng. Applied Sci, 9, 178-186.

Letellier, P., Mayaffre, A., \& Turmine, M. (2007). Drop size effect on contact angle explained by nonextensive thermodynamics. Young's equation revisited. Journal of colloid and interface science, 314(2), 604-614.

Lubis, Z., Abdalla, A. N., Mortaza, M., \& Ghon, R. (2009). Mathematical Modeling of the Three Phase Induction Motor Couple to DC Motor in Hybrid Electric Vehicle. American Journal of Engineering and Applied Sciences, 2(4).

Malomar, G. E., Gueye, A., Mbow, C., Traore, V. B., \& Beye, A. C. (2016). Numerical study of natural convection in a square porous cavity thermally modulated on both side walls. Am. J. Eng. Applied Sci, 9, 591-598.

Mansour, M. A. (2016). Developing an anthropometric database for Saudi students and comparing Saudi dimensions relative to Turkish and Iranian peoples. American Journal of Engineering and Applied Sciences, 9(3), 547-557.

Marghany, M., \& Hashim, M. (2009). Robust of doppler centroid for mapping sea surface current by using radar satellite data. Am. J. Eng. Applied Sci, 2, 781-788.

Martins, F. R., Gonçalves, A. R., \& Pereira, E. B. (2016). Observational study of wind shear in northeastern Brazil. Am. J. Eng. Applied Sci, 9, 484-504.

Mason, C. W. (1923). Structural colours in feathers. II. The Journal of Physical Chemistry, 27(5), 401-448.

Mattox, D. M. (1964). Film deposition using accelerated ions (No. SC-DR-281-63). Sandia Lab., Albuquerque, N. Mex.

Mavukkandy, M. O., Chakraborty, S., Abbasi, T., \& Abbasi, S. A. (2016). A clean-green synthesis of platinum nanoparticles utilizing a pernicious weed lantana (Lantana Camara). Am. J. Eng. Applied Sci, 9, 84-90.

Meiron, T. S., Marmur, A., \& Saguy, I. S. (2004). Contact angle measurement on rough surfaces. Journal of colloid and interface science, 274(2), 637-644.

Minghini, F., Tullini, N., \& Ascione, F. (2016). Updating Italian design guide CNR DT-205/2007 in view of recent research findings: Requirements for pultruded FRP profiles.

Misiano, C. (2001). Cost-Effective High Performance Coatings by Ion Plating. In Proceedings of the annual technical Conference-society of vacuum coaters (pp. 116-119). 
Misiano, C., \& Scandurra, R. (2006). U.S. Patent Application No. 12/011,018.

Moezi, N., Dideban, D., \& Ketabi, A. (2008). A novel integrated SET based inverter for nano power electronic applications. Am. J. Eng. Applied Sci, 1, 219-222.

Mohamed, M. A., Tuama, A. Y., Makhtar, M., Awang, M. K., \& Mamat, M. (2016). The effect of RSA exponential key growth on the multi-core computational resource. Am. J. Eng. Applied Sci, 9, 1054-1061.

Mohan, S. R. K., Jayabalan, P., \& Rajaraman, A. (2012). Properties of fly ash based coconut fiber composite. American Journal of Engineering and Applied Sciences, 5(1).

Mohseni, E., \& Tsavdaridis, K. D. (2016). Effect of nanoalumina on pore structure and durability of Class F Fly ash self-compacting mortar. American Journal of Engineering and Applied Sciences, 9(2), 323-333.

Momani, M. A., Al Smadi, T. A., Al Taweel, F. M., \& Ghaidan, K. A. (2011). GPS ionospheric total electron content and scintillation measurements during the October 2003 magnetic storm. Am. J. Eng. Applied Sci, 4, 301-306.

Mondal, R., Sahoo, S., \& Rout, C. S. (2016). Mixed nickel cobalt manganese oxide nanorods for supercapacitor application.

Montgomery, J., Abu-Lebdeh, T. M., Hamoush, S. A., \& Picornell, M. (2016). Effect of nano-silica on the compressive strength of harden cement paste at different stages of hydration. Am. J. Eng. Applied Sci, 9, 166-177.

Morse, A., Mansfield, M. M., Alley, R. M., Kerr, H. A., \& Bucinell, R. B. (2016). Traction enhancing products affect maximum torque at the shoe-floor interface: A potential increased risk of ACL injury. Am. J. Eng. Applied Sci, 9, 889-893.

Moubarek, T., \& Gharsallah, A. (2016). A six-port reflectometer calibration using Wilkinson power divider. Am. J. Eng. Applied Sci, 9, 274-280.

Nabilou, A. (2016). Effect of parameters of selection and replacement drilling bits based on geomechanical factors:(Case study: Gas and oil reservoir in the Southwest of Iran). Am. J. Eng. Applied Sci, 9, 380-395.

Nabilou, A., Carvalho, M. T., Dias, N., Brogueira, P., Salamunićcar, G., Loncaric, S.,... \& Gonçalves, M. C. (2016). Study of the parameters of Steam Assisted Gravity Drainage (SAGD) method for enhanced oil recovery in a heavy oil fractured carbonate reservoir. Am. J. Eng. Applied Sci, 9, 647-658.

Nachiengtai, T., Chim-Oye, W., Teachavorasinskun, S., \& Sa-Ngiamvibool, W. (2008). Identification of shear band using elastic shear wave propagation. American Journal of Engineering and Applied Sciences, 1(3).
Nahas, R., \& Kozaitis, S. P. (2014). Metric for the fusion of synthetic and real imagery from multimodal sensors. American Journal of Engineering and Applied Sciences, 7(4), 355.

Nandhakumar, S., Selladurai, V., \& Sekar, S. (2009). Numerical investigation of an industrial robot arm control problem using haar wavelet series. American Journal of Engineering and Applied Sciences, 2(4).

Newton, I. (1952). Opticks, or, a treatise of the reflections, refractions, inflections \& colours of light. Courier Corporation.

Ng, K. C., Yusoff, M. Z., Munisamy, K., Hasini, H., \& Shuaib, N. H. (2008). Time-marching method for computations of high-speed compressible flow on structured and unstructured grid. Am. J. Eng. Applied Sci, 1(2), 89-94.

Nosonovsky, M., \& Bhushan, B. (2008). Multiscale dissipative mechanisms and hierarchical surfaces: Friction, superhydrophobicity and biomimetics. Springer Science \& Business Media.

Obaiys, S. J., Abbas, Z., Long, N. N., Ahmad, A. F., Ahmedov, A., \& Raad, H. K. (2016). On the general solution of first-kind hypersingular integral equations. Am. J. Eng. Applied Sci, 9, 195-201.

Odeh, S., Faqeh, R., Eid, L. A., \& Shamasneh, N. (2009). Vision-based obstacle avoidance of mobile robot using quantized spatial model. Am. J. Eng. Applied Sci, 2, 611-619.

Opafunso, Z. O., Ozigis, I. I., \& Adetunde, I. A. (2009). Pneumatic and hydraulic systems in coal fluidized bed combustor. Am. J. Eng. Applied Sci, 2, 88-95.

Orlando, N., \& Benvenuti, E. (2016). Advanced XFEM simulation of pull-out and debonding of steel bars and FRP-reinforcements in concrete beams. Am. J. Eng. Applied Sci, 9, 746-754.

Pannirselvam, N., Raghunath, P. N., \& Suguna, K. (2008). Neural network for performance of glass fibre reinforced polymer plated RC beams. Am. J. Eng. Applied Sci, 1(1), 82-88.

Patankar, N. A. (2003). On the modeling of hydrophobic contact angles on rough surfaces. Langmuir, 19(4), 1249-1253.

Pattanasethanon, S. (2010). The solar tracking system by using digital solar position sensor. American Journal of Engineering and Applied Sciences, 3(4), 678-682.

Pérez-de León, G. Lamberti, V. E. Seals, R. D. AbuLebdeh, T. M., \& Hamoush, S. A. (2016). Gas Atomization of Molten Metal: Part I. Numerical Modeling Conception. Am. J. Eng. Applied Sci. 9(2):303-322.

Petrescu, F. I. (2015a). Geometrical synthesis of the distribution mechanisms. American Journal of Engineering and Applied Sciences, 8(1), 63-81.

Petrescu, F. I. T. (2015b). Machine motion equations at the internal combustion heat engines. American Journal of Engineering and Applied Sciences, 8(1), 127-137. 
Petrescu, F. I. T., \& Petrescu R. V., (2014d). Gear Design, In journal ENGEVISTA, Vol. 16, No. 4, p. 313-328

Petrescu, F. I. T., \& Petrescu, R. V. (2013f). An algorithm for setting the dynamic parameters of the classic distribution mechanism. Int. Rev. Modell. Simulat, 6, 1637-1641.

Petrescu, F. I. T., \& Petrescu, R. V. (2014g). Machine equations to the classical distribution. Int. Rev. Mech. Eng, 8, 309-316.

Petrescu, F. I. T., \& Petrescu, R. V. (2014h). Forces of internal combustion heat engines. Int. Rev. Modell. Simulat, 7, 206-212.

Petrescu, F. I. T., \& Petrescu, R. V. (2014i). Determination of the yield of internal combustion thermal engines. Int. Rev. Mech. Eng, 8, 62-67.

Petrescu, F. I. T., \& Petrescu, R. V. (2015c). Machine Motion Equations, Independent Journal of Management \& Production, 6(3), pp. 773-802

Petrescu, F. I. T., 2012a. Cold nuclear fusion. Plasma Phys. Fusion Technol., 44: 100-100.

Petrescu, F. I., \& Calautit, J. K. (2016a). About nano fusion and dynamic fusion. American Journal of Applied Sciences, 13(3).

Petrescu, F. I., \& Calautit, J. K. (2016b). About the light dimensions. American Journal of Applied Sciences, 13(3).

Petrescu, F. I., \& Petrescu, R. V. (2005a). The cam design for a better efficiency. Available at SSRN 3076805.

Petrescu, F. I., \& Petrescu, R. V. (2005b, September). Contributions at the Dynamic of Cams. In The Ninth IFTOMM International Symposium on Theory of Machines and Mechanisms.

Petrescu, F. I., \& Petrescu, R. V. (2005c). Determining the dynamic efficiency of cams. Available at SSRN 3076802.

Petrescu, F. I., \& Petrescu, R. V. (2005d). An original internal combustion engine. In The Ninth IFTOMM International Symposium on Theory of Machines and Mechanisms.

Petrescu, F. I., \& Petrescu, R. V. (2011). Memories about Flight!. Create Space Publisher.

Petrescu, F. I., \& Petrescu, R. V. (2012). New Aircraft II: Germany 2012. BoD-Books on Demand.

Petrescu, F. I., \& Petrescu, R. V. (2013d). Forces and efficiency of cams. Int. Rev. Mech. Eng, 7(3), 507-511.

Petrescu, F. I., \& Petrescu, R. V. (2013g). Dynamic synthesis of the rotary cam and translated tappet with roll. Engevista, 15(3).

Petrescu, F. I., \& Petrescu, R. V. (2014a). Parallel moving mechanical systems. Independent Journal of Management \& Production (IJM\&P), 5(3).

Petrescu, F. I., \& Petrescu, R. V. (2014b). Cam gears dynamics in the classic distribution. Independent Journal of Management \& Production (IJM\&P), 5(1).
Petrescu, F. I., \& Petrescu, R. V. (2014c). Highefficiency gears synthesis by avoid the interferences. Independent Journal of Management \& Production (IJM\&P), 5(2).

Petrescu, F. I., \& Petrescu, R. V. (2014e). Kinetostatic of the 3r dyad. Engevista, 16(3), 314-321.

Petrescu, F. I., \& Petrescu, R. V. (2015a). Forces at the main mechanism of a railbound forging manipulator. Independent Journal of Management \& Production, 6(4).

Petrescu, F. I., \& Petrescu, R. V. (2015b). Kinematics at the main mechanism of a railbound forging manipulator. Independent Journal of Management \& Production, 6(3).

Petrescu, F. I., \& Petrescu, R. V. (2015d). Presenting a railbound forging manipulator. In Applied Mechanics and Materials (Vol. 762, pp. 219-224). Trans Tech Publications Ltd.

Petrescu, F. I., \& Petrescu, R. V. (2016). An otto engine dynamic model. Independent Journal of Management \& Production (IJM\&P), 7(1).

Petrescu, F. I., Apicella, A., Petrescu, R. V., Kozaitis, S., Bucinell, R., Aversa, R., \& Abu-Lebdeh, T. (2016). Environmental protection through nuclear energy. American Journal of Applied Sciences, 13(9), 941-946.

Petrescu, F., \& Petrescu, R. (1995a). Contributions to optimization of the polynomial motion laws of the stick from the internal combustion engine distribution mechanism. Bucharest, 1, 249-256.

Petrescu, F., \& Petrescu, R. (1995b). Contributions to the synthesis of internal combustion engine distribution mechanisms. Bucharest, 1, 257-264.

Petrescu, F., \& Petrescu, R. (1997a). Dynamics of cam mechanisms (exemplified on the classic distribution mechanism). Bucharest, 3, 353-358.

Petrescu, F., \& Petrescu, R. (1997b). Contributions to the synthesis of the distribution mechanisms of internal combustion engines with a Cartesian coordinate method. Bucharest, 3, 359-364.

Petrescu, F., \& Petrescu, R. (1997c). Contributions to maximizing polynomial laws for the active stroke of the distribution mechanism from internal combustion engines. Bucharest, 3, 365-370.

Petrescu, F., \& Petrescu, R. (2000a). Synthesis of distribution mechanisms by the rectangular (Cartesian) coordinate method. University of Craiova, Craiova.

Petrescu, F., \& Petrescu, R. (2000b). The design (synthesis) of cams using the polar coordinate method (triangle method). University of Craiova, Craiova.

Petrescu, F., \& Petrescu, R. (2002a). Motion laws for cam mechanisms. In the 7th National Symposium with International Participation Computer Assisted Design, PRASIC'02, Braşov. 2002, Vol. I, pp. 321-326. 
Petrescu, F., \& Petrescu, R. (2002b). Dynamics of cam mechanisms. In Proceedings of the National Symposium with International Participation Computer Assisted Design,(CAD’02), Brasov (pp. 327-332).

Petrescu, F., \& Petrescu, R. (2003). Some elements regarding the improvement of the engine design. In Proceedings of the National Symposium, Descriptive Geometry, Technical Graphics and Design,(GTD'03), Braşov (pp. 353-358).

Petrescu, F.I.T. (2012b). China. CreateSpace Independent Publisher, 232 pages, ISBN-13: 9781469973623Petrescu, F. I. T. (2018). About the nuclear particles' structure and dimensions. Computational Particle Mechanics, 6(2), 191-194.

Petrescu, F.I.T., \& Petrescu, R.V. (2013e). Cams with High Efficiency, International Review of Mechanical Engineering (I.RE.M.E. Journal), Vol. 7, N. 4, p. 599-606

Petrescu, F.I.T., \& Petrescu, R.V. (2014f). Balancing Otto Engines, International Review of Mechanical Engineering (I.RE.M.E. Journal), Vol. 8, N. 3, p. 473-480

Petrescu, F.I.T., \& Petrescu, R.V. (2015e). About the Anthropomorphic Robots, In journal ENGEVISTA, Vol. 17, No. 1, p. 1-15

Petrescu, R. V., \& Petrescu, F. I. (2005e). Determining the mechanical efficiency of Otto engine's mechanism. Available at SSRN 3076804.

Petrescu, R. V., \& Petrescu, F. I. (2013c). The Aviation History or New Aircraft I Colour.

Petrescu, R. V., Aversa, R., Akash, B., Berto, F., Apicella, A., \& Petrescu, F. I. (2017a). Forces of a 3R robot. Journal of Mechatronics and Robotics, 1(1).

Petrescu, R. V., Aversa, R., Akash, B., Berto, F., Apicella, A., \& Petrescu, F. I. (2017b). Direct geometry and cinematic to the MP-3R systems. Journal of Mechatronics and Robotics, 1(1).

Petrescu, R. V., Aversa, R., Akash, B., Berto, F., Apicella, A., \& Petrescu, F. I. (2017c). Dynamic elements at MP3R. Journal of Mechatronics and Robotics, 1(2), 24-37.

Petrescu, R. V., Aversa, R., Akash, B., Berto, F., Apicella, A., \& Petrescu, F. I. (2017d). Geometry and direct kinematics to MP3R with $4 \times 4$ operators. Journal of Mechatronics and Robotics, 1(2), 38-46.

Petrescu, R. V., Aversa, R., Apicella, A., \& Petrescu, F. I. (2018a). Total static balancing and kinetostatics of the 3R base cinematic Chain. Journal of Mechatronics and Robotics, 2(1), 1-13.

Petrescu, R. V., Aversa, R., Apicella, A., \& Petrescu, F. I. (2018b). Switching from flat to spatial motion to 3R mechatronic systems. Journal of Mechatronics and Robotics, 2(1), 14-22.
Petrescu, R. V., Aversa, R., Apicella, A., \& Petrescu, F. I. (2018c). The dynamics of the planar cinematic balanced chain at the plan module $3 \mathrm{R}$. Journal of Mechatronics and Robotics, 2(1), 23-34.

Petrescu, R. V., Aversa, R., Apicella, A., \& Petrescu, F. I. (2018d). Dynamic kinematics of the plan balanced chain at the planar module 3R. Journal of Mechatronics and Robotics, 2(1), 35-44.

Petrescu, R.V., \& Petrescu, F.I. (2013a). Lockheed Martin. 1st Edn., BoD-Books on Demand, ISBN-10: 3848230739, pp: 114.

Petrescu, R.V., \& Petrescu, F.I. (2013b). Northrop. 1st Edn., CreateSpace, pp: 96.

Pisello, A. L., Pignatta, G., Piselli, C., Castaldo, V. L., \& Cotana, F. (2016). Investigating the dynamic thermal behavior of building envelope in summer conditions by means of in-field continuous monitoring. Am. J. Eng. Applied Sci, 9, 505-519.

Pourmahmoud, N. (2008). Rarefied gas flow modeling inside rotating circular cylinder. Am. J. Eng. Applied Sci, 1(1), 62-65.

Pravettoni, M., Polo Lopez, C. S., \& Kenny, R. P. (2016). Impact of the edges of a backside diffusive reflector on the external quantum efficiency of luminescent solar concentrators: Experimental and computational approach. American Journal of Engineering and Applied Sciences, 9(1), 53-63.

Qutbodin, K. (2010). Merging autopilot/flight control and navigation-flight management systems. Am. J. Eng. Applied Sci, 3, 629-630.

Rajbhandari, S., Ghassemlooy, Z., \& Angelova, M. (2011). The performance of a dual header pulse position modulation in the presence of artificial light interferences in an indoor optical wireless communications channel with wavelet denoising. American Journal of Engineering and Applied Sciences, 4(4), 513-519.

Rajput, R. S., Pandey, S., \& Bhadauria, S. (2016). Correlation of biodiversity of algal genera with special reference to the waste water effluents from industries. Am. J. Eng. Applied Sci, 9, 1127-1133.

Rama, G., Marinković, D., \& Zehn, M. (2016). Efficient co-rotational 3-node shell element. American Journal of Engineering and Applied Sciences.

Raptis, K. G., Papadopoulos, G. A., Costopoulos, T. N., \& Tsolakis, A. D. (2011). Experimental study of load sharing in roller-bearing contact by caustics and photoelasticity. Am. J. Eng. Applied Sci, 4, 294-300.

Rayleigh, L. (1917). Roy. Soc. Proc., A93, 565- 577.

Rayleigh, L. (1919). VII. On the optical character of some brilliant animal colours. The London, Edinburgh and Dublin Philosophical Magazine and Journal of Science, 37(217), 98-111.

Rea, P., \& Ottaviano, E. (2016). Analysis and mechanical design solutions for sit-to-stand assisting devices. Am. J. Eng. Applied Sci, 9, 1134-1143. 
Riccio, A., Caruso, U., Raimondo, A., \& Sellitto, A. (2016a). Robustness of XFEM method for the simulation of cracks propagation in fracture mechanics problems.

Riccio, A., Cristiano, R., \& Saputo, S. (2016b). A brief introduction to the bird strike numerical simulation.

Rich, F., \& Badar, M. A. (2016). Statistical analysis of auto dilution Vs manual dilution process in inductively coupled plasma spectrometer tests. Am. J. Eng. Applied Sci, 9, 611-624.

Rohit, K., \& Dixit, S. (2016). Mechanical properties of waste Biaxially Oriented Polypropylene metallized films (BOPP), LLDPE: LDPE films with sisal fibres. Am. J. Eng. Applied Sci, 9, 913-920.

Rulkov, N. F., Hunt, A. M., Rulkov, P. N., \& Maksimov, A. G. (2016). Quantization of map-based neuronal model for embedded simulations of neurobiological networks in real-time. American Journal of Engineering and Applied Sciences, 9(4), 973-984.

Saikia, A., \& Karak, N. (2016). Castor oil based epoxy/clay nanocomposite for advanced applications. Am. J. Eng. Applied Sci, 9, 31-40.

Sallami, A., Zanzouri, N., \& Ksouri, M. (2016). Robust diagnosis of a DC motor by bond graph approach. Am. J. Eng. Applied Sci, 9, 432-438.

Samantaray, K. S., Sahoo, S., \& Rout, C. S. (2016). Hydrothermal synthesis of CuWO4-reduced graphene oxide hybrids and supercapacitor application. Am. J. Eng. Applied Sci, 9, 584-590.

Semin, R. A. B. (2008). A technical review of compressed natural gas as an alternative fuel for internal combustion engines. Am. J. Eng. Appl. Sci, 1(4), 302-311.

Semin, S., Ismail, A. R., \& Bakar, R. A. (2009a). Combustion temperature effect of diesel engine convert to compressed natural gas engine. American Journal of Engineering and Applied Sciences, 2(1).

Semin, S., Ismail, A. R., \& Bakar, R. A. (2009b). Diesel engine convert to port injection $\mathrm{CNG}$ engine using gaseous injector nozzle multi holes geometries improvement: A review. American Journal of Engineering and Applied Sciences, 2(2).

Semin, S., Ismail, A. R., \& Bakar, R. A. (2009c). Effect of diesel engine converted to sequential port injection compressed natural gas engine on the cylinder pressure vs Crank angle in variation engine speeds. American Journal of Engineering and Applied Sciences, 2(1).

Sepúlveda, J. A. M. (2016). Outlook of municipal solid waste in Bogota (Colombia). Am. J. Eng. Applied Sci, 9, 477-483.

Serebrennikov, A., Serebrennikov, D., \& Hakimov, Z. (2016). Polyethylene pipeline bending stresses at an installation. Am. J. Eng. Applied Sci, 9, 350-355.
Shanmugam, K. (2016). Flow dynamic behavior of fish oil/silver nitrate solution in mini-channel, effect of alkane addition on flow pattern and interfacial tension. Am. J. Eng. Applied Sci, 9, 236-250.

Shruti, (2016). Comparison in Cover Media under Stegnography: Digital Media by Hide and Seek Approach. Am. J. Eng. Applied Sci. 9(2):297-302. DOI: 10.3844/ajeassp.2016.297.302

Silva, T. P., Figueiredo, M. O., \& Prudêncio, M. I. (2013). Ascertaining the degradation state of ceramic tiles: A preliminary non-destructive step in view of conservation treatments. Applied Clay Science, 82, 101-105.

Soeno, T., Inokuchi, K., \& Shiratori, S. (2004). Ultra-waterrepellent surface: Fabrication of complicated structure of $\mathrm{SiO} 2$ nanoparticles by electrostatic self-assembled films. Applied surface science, 237(1-4), 539-543.

Spori, D. M., Drobek, T., Zürcher, S., Ochsner, M., Sprecher, C., Mühlebach, A., \& Spencer, N. D. (2008). Beyond the lotus effect: Roughness influences on wetting over a wide surface-energy range. Langmuir, 24(10), 5411-5417.

Suarez, L., Abu-Lebdeh, T. M., Picornell, M., \& Hamoush, S. A. (2016). Investigating the role of fly ash and silica fume in the cement hydration process. Am. J. Eng. Applied Sci, 9, 134-145.

Syahrullah, L. O. I., \& SINAGA, N. (2016). Optimization and prediction of motorcycle injection system performance with feed-forward backpropagation method Artificial Neural Network (ANN). American Journal of Engineering and Applied Science, 9(2), 222-235.

Taher, S. A., Hematti, R., \& Nemati, M. (2008). Comparison of different control strategies in GAbased optimized UPFC controller in electric power systems. Am. J. Eng. Applied Sci, 1(1), 45-52.

Theansuwan, W., Sriprateep, K., \& Palaprom, A. (2011, July). The biodiesel production from roast Thai sausage oil by transesterification reaction. In ITCCSCC: International Technical Conference on Circuits Systems, Computers and Communications (pp. 1-4).

Thongwan, T., Kangrang, A., \& Homwuttiwong, S. (2011). An estimation of rainfall using fuzzy setgenetic algorithms model. Am. J. Eng. Applied Sci, 4, 77-81.

Tourab, W., Babouri, A., \& Nemamcha, M. (2011). Experimental study of electromagnetic environment in the vicinity of high voltage lines. Am. J. Eng. Applied Sci, 4, 209-213.

Tsolakis, A. D., \& Raptis, K. G. (2011). Comparison of maximum gear-tooth operating bending stresses derived from niemann's analytical procedure and the finite element method. Am. J. Eng. Applied Sci, 4, 350-354. 
Ventolà, L., Cordoba, A., Vendrell-Saz, M., Giraldez, P., Vilardell, R., \& Saline, M. (2014). Decorated ceramic tiles used in Catalan Modernist Architecture (c. 1870 to c. 1925): Composition, decay and conservation. Construction and Building Materials, 51, 249-257.

Vukusic, P., Sambles, J. R., Lawrence, C. R., \& Wootton, R. J. (1999). Quantified interference and diffraction in single Morpho butterfly scales. Proceedings of the Royal Society of London. Series B: Biological Sciences, 266(1427), 1403-1411.

Wang, J., \& Yagi, Y. (2016). Fragment-based visual tracking with multiple representations. Am. J. Eng. Applied Sci, 9, 187-194.

Wang, L., Liu, T., Zhang, Y., \& Yuan, X. (2016). A methodology for continuous evaluation of cloud resiliency. Am. J. Eng. Applied Sci, 9, 264-273.

Waters, C., Ajinola, S., \& Salih, M. (2016). Dissolution sintering technique to create porous copper with sodium chloride using polyvinyl alcohol solution through powder metallurgy. Am. J. Eng. Applied Sci, 9, 155-165.

Wessels, L., \& Raad, H. (2016). Recent advances in point of care diagnostic tools: A review. Am. J. Eng. Applied Sci, 9, 1088-1095.

Yeargin, R., Ramey, R., \& Waters, C. (2016). Porosity analysis in porous brass using dual approaches. Am. J. Eng. Applied Sci, 9, 91-97.

Yoshimitsu, Z., Nakajima, A., Watanabe, T., \& Hashimoto, K. (2002). Effects of surface structure on the hydrophobicity and sliding behavior of water droplets. Langmuir, 18(15), 5818-5822.
You, M., Huang, X., Lin, M., Tong, Q., \& Li, X. (2016). Preparation of LiCoMnO4 assisted by hydrothermal approach and its electrochemical performance. Am. J. Eng. Applied Sci, 9, 396-405.

Zeferino, R. S., Ramón, J. R., de Anda Reyes, E., Gónzalez, R. S., \& Pal, U. (2016). Large scale synthesis of $\mathrm{ZnO}$ nanostructures of different morphologies through solvent-free mechanochemical synthesis and their application in photocatalytic dye degradation. Am. J. Eng. Applied Sci, 9, 41-52.

Zhao, B. (2013). Identification of multi-cracks in the gate rotor shaft based on the wavelet finite element method. Am. J. Eng. Applied Sci, 6, 309-319.

Zheng, H., \& Li, S. (2016). Fast and robust maximum power point tracking for solar photovoltaic systems. Am. J. Eng. Applied Sci, 9, 755-769.

Zotos, I. S., \& Costopoulos, T. N. (2009). On the use of rolling element bearings' models in precision maintenance. Am. J. Eng. Applied Sci, 2, 344-352.

Zulkifli, R., Sopian, K., Abdullah, S., \& Takriff, M. S. (2008). Effect of pulsating circular hot air jet frequencies on local and average nusselt number. American Journal of Engineering and Applied Sciences, 1(1), 57-61.

Zulkifli, R., Sopian, K., Abdullah, S., \& Takriff, M. S. (2009). Experimental study of flow structures of circular pulsating air jet. American Journal of Engineering and Applied Sciences, 2(1).

Zurfi, A., \& Zhang, J. (2016a). Model identification and wall-plug efficiency measurement of white LED modules. Am. J. Eng. Applied Sci, 9, 412-419.

Zurfi, A., \& Zhang, J. (2016b). Exploitation of battery energy storage in load frequency control-a literature survey. Am. J. Eng. Applied Sci, 9, 1173-1188. 